\title{
Geochemical processes and chemosynthetic primary production in different thiotrophic mats of the Håkon Mosby Mud Volcano (Barents Sea)
}

\author{
Anna Lichtschlag, ${ }^{\mathrm{a},}{ }^{*}$ Janine Felden, ${ }^{a}$ Volker Brüchert, ${ }^{\mathrm{a}, 1}$ Antje Boetius, ${ }^{\mathrm{a}, \mathrm{b}, \mathrm{c}}$ and Dirk de Beera \\ a Max-Planck-Institute for Marine Microbiology, Bremen, Germany \\ ${ }^{\mathrm{b}}$ Center for Marine Environmental Sciences, University of Bremen, Bremen, Germany \\ c Helmholtz-Gemeinschaft deutscher Forschungszentren-Max-Planck-Gesellschaft Joint Research Group on Deep Sea Ecology and \\ Technology, Alfred Wegener Institute for Polar and Marine Research, Bremerhaven, Germany
}

\begin{abstract}
We have investigated if in a cold seep methane or sulfide is used for chemosynthetic primary production and if significant amounts of the sulfide produced by anaerobic oxidation of methane are oxidized geochemically and hence are not available for chemosynthetic production. Geochemically controlled redox reactions and biological turnover were compared in different habitats of the Håkon Mosby Mud Volcano. The center of the mud volcano is characterized by the highest fluid flow, and most primary production by the microbial community depends on oxidation of methane. The small amount of sulfide produced is oxidized geochemically with oxygen or is precipitated with dissolved iron. In the medium flow peripheral Beggiatoa habitat sulfide is largely oxidized biologically. The oxygen and nitrate supply is high enough that Beggiatoa can oxidize the sulfide completely, and chemical sulfide oxidation or precipitation is not important. An internally stored nitrate reservoir with average concentrations of $110 \mathrm{mmol} \mathrm{L}^{-1}$ enables the Beggiatoa to oxidize sulfide anaerobically. The $\mathrm{pH}$ profile indicates sequential sulfide oxidation with elemental sulfur as an intermediate. Gray thiotrophic mats associated with perturbed sediments showed a high heterogeneity in sulfate turnover and high sulfide fluxes, balanced by the opposing oxygen and nitrate fluxes so that biological oxidation dominates over geochemical sulfide removal processes. The three habitats indicate substantial small-scale variability in carbon fixation pathways, either through direct biological use of methane or through indirect carbon fixation of methane-derived carbon dioxide by chemolithotrophic sulfide oxidation.
\end{abstract}

Geochemical and microbiological processes at cold seeps, such as mud volcanoes, surface gas hydrate deposits, and methane-laden pockmarks, differ significantly from processes in organic detritus-fueled deep-sea sediments. At cold seeps, methane is abundant near the sediment-water interface, and methane-consuming microbial communities control its discharge to the water column (Boetius and Suess 2004; Niemann et al. 2006; Wallmann et al. 2006). The key process in methane-rich seafloor sediment is the microbially mediated anaerobic oxidation of methane (AOM) coupled to sulfate reduction (Boetius et al. 2000). One product of this process is dissolved sulfide. Not much is known about the fate of AOM-produced sulfide in cold seep sediments, but previous work (Sahling et al. 2002; de Beer et al. 2006) indicated that it is almost completely oxidized biologically within the seabed.

Both biological and geochemical processes can remove sulfide. In many cold seep ecosystems different thiotrophic communities gain energy from the chemolithoautotrophic oxidation of sulfide, such as the symbiotic siboglinid tubeworms (Cordes et al. 2005; Lösekann et al. 2008) and diverse bivalves, including mytilids, lucinids, and vesicomyids (Sibuet and Olu 1998; Duperron et al. 2005). Freeliving thiotrophic bacteria form extensive mats, and representatives of these mat-forming organisms are giant

\section{* Corresponding author: alichtsc@mpi-bremen.de}

${ }^{1}$ Present address: Department of Geology and Geochemistry, Stockholm University, Stockholm, Sweden vacuolated sulfur-oxidizing Gammaproteobacteria like Beggiatoa, Thiomargarita, or Thioploca. Many members of these groups are able to store both nitrate and elemental sulfur intracellularly (McHatton et al. 1996; Teske and Nelson 2006). Thiomargarita are sessile, spherical bacteria, whereas Beggiatoa and Thioploca are motile filamentous bacteria that are able to glide. Beggiatoa can move downward to a sediment zone where dissolved sulfide is abundant and can use the stored nitrate as electron acceptor, either oxidizing sulfide to sulfate (Eq. 1) or to elemental sulfur (Eq. 2), thus

$$
\begin{aligned}
& \mathrm{HS}^{-}+\mathrm{NO}_{3}^{-}+\mathrm{H}^{+}+\mathrm{H}_{2} \mathrm{O} \rightarrow \mathrm{NH}_{4}^{+}+\mathrm{SO}_{4}^{2-} \\
& 4 \mathrm{HS}^{-}+\mathrm{NO}_{3}^{-}+6 \mathrm{H}^{+} \rightarrow 4 \mathrm{~S}^{0}+\mathrm{NH}_{4}^{+}+3 \mathrm{H}_{2} \mathrm{O}
\end{aligned}
$$

In the upper zone of the sediment, where oxygen and nitrate are available but sulfide is depleted, they refill their vacuoles with nitrate and oxidize the internally stored sulfur aerobically, thus

$$
2 \mathrm{~S}^{0}+3 \mathrm{O}_{2}+2 \mathrm{H}_{2} \mathrm{O} \rightarrow 2 \mathrm{SO}_{4}^{2-}+4 \mathrm{H}^{+}
$$

The most important abiotic process is the precipitation of sulfide with iron oxides. Iron oxides react with sulfide, forming mainly elemental sulfur and metastable, amorphous iron sulfides. These metastable iron sulfides can be converted to the stable species pyrite $\left(\mathrm{FeS}_{2}\right)$, e.g., by reaction with polysulfides (Drobner et al. 1990) or by reaction with polysulfides (Luther 1991). Iron sulfides are 
either buried in the sediment or remain part of the sulfur and iron cycle by transport to the oxic zone (e.g., by bioturbation), where they are re-oxidized. The oxidized iron is again available as an electron acceptor for sulfide. In some marine settings, such as coastal zones, geochemical sulfide precipitation can totally dominate over microbial oxidation by Beggiatoa (Preisler et al. 2007). In the sediments of Limfjorden (Denmark) Beggiatoa is responsible for up to $50 \%$ of the sulfide oxidation (Mussmann et al. 2003). Thioploca off the coast of Chile mediate maximally one third of the total sulfide oxidation (Ferdelman et al. 1997). The causes for this variation in the partitioning of biotic and abiotic sulfide oxidation in marine sediments are not well constrained. At cold seeps in deep waters the distribution of biotic and abiotic processes in sulfide oxidation has not been investigated.

The Håkon Mosby Mud Volcano is characterized by large gradients in fluid flow velocities and sulfide fluxes (de Beer et al. 2006), and, hence, it represents an ideal natural laboratory in which to study the processes involved in sulfide consumption at cold seeps. The different fluid flow zones include (1) the central mud flows (fluid flow velocity: $>3-6 \mathrm{~m} \mathrm{yr}^{-1}$ ) dominated by aerobic methane oxidation, (2) Beggiatoa mats (fluid flow velocity: $0.3-1 \mathrm{~m} \mathrm{yr}^{-1}$ ), and (3) gray mats (de Beer et al. 2006; Niemann et al. 2006; Lösekann et al. 2007). We have not studied the large outer rim of the Håkon Mosby Mud Volcano populated by thiotrophic siboglinid tubeworms (Lösekann et al. 2008) as we could not obtain in situ microsensor measurements from the dense subseafloor system of tubeworm roots. Part of the primary production at the Håkon Mosby Mud Volcano is based on the energy generation from microbial sulfide oxidation, and geochemical sulfide oxidation with iron oxides or other electron acceptors could potentially reduce the sulfide supply to bacteria and, hence, the energy and carbon supply to this chemosynthetic ecosystem.

Thus, our aims were (1) to determine if geochemical or biological processes dominate sulfide removal, (2) to determine whether methane or sulfide is used for chemosynthetic biomass production, and (3) to estimate the areal primary production of the different microbial habitats. To answer these questions, the key pathways in sulfide oxidation were investigated, including the turnover of the geochemically and biologically relevant components $\left(\mathrm{SO}_{4}^{2-}, \mathrm{O}_{2}, \mathrm{NO}_{3}^{-}\right)$, the efflux of the emanating products (mainly $\mathrm{HS}^{-}$, dissolved inorganic carbon [DIC]), and the distribution of sulfide oxidizers. To circumvent biases introduced by degassing during the retrieval of methaneladen cores from the deep seafloor, in situ measurements were conducted.

\section{Methods}

Sampling site-The Håkon Mosby Mud Volcano is situated on the Norwegian-Barents-Svalbard continental margin $\left(72^{\circ} 00.3^{\prime} \mathrm{N}, 14^{\circ} 44.0^{\prime} \mathrm{E}\right)$. It is located at a water depth of $1250 \mathrm{~m}$ and has a concentric shape with a diameter of $1 \mathrm{~km}$ and an elevation above the seafloor of 8-10 m (Vogt et al. 1997). The sediment layer thickness above the oceanic crust is more than $6 \mathrm{~km}$, and the deposits consist of Eocene-Pliocene preglacial hemipelagic sediments and Late Pliocene-Pleistocene glacial-marine sediments (Hjelstuen et al. 1999). The pore water rising in the Håkon Mosby Mud Volcano is highly enriched in methane, and gas hydrates form around the central conduits for fluid flow (Milkov et al. 2004; Niemann et al. 2006).

Sampling - Sampling and measurements were performed in 2003 during the ARK XIX/3b cruise with the R/V Polarstern (PS64), in 2005 with the R/V L'Atalante (ATL05/02-3), and in 2006 during the HERMES (Hotspot Ecosystem Research on the Margins of European Seas) cruise Viking (Ifremer) with the R/V Pourquoi pas?. On all expeditions the remotely operated vehicle (ROV) Victor 6000 (Ifremer) was used for sampling and positioning of instruments. Sampling and measurement details are summarized in Table 1, and sites are displayed in Fig. 1.

Push core samples with a sediment length of $15-20 \mathrm{~cm}$ were obtained with the ROV manipulator. Cores with 25$30 \mathrm{~cm}$ sediment length were obtained with a multiple corer device (MUC), equipped with a Posidonia positioning system. As high gas load and decrease in pressure caused outgassing and sediment surface disturbances during retrieval, the sediment-filled liners were stored at in situ temperature $\left(0^{\circ} \mathrm{C}\right)$ for $1 \mathrm{~d}$ so that the mats appeared again and the geochemical gradients were re-established. Subsequently the cores were transferred to a $4^{\circ} \mathrm{C}$ room for porewater extraction with Rhizons (type: core solution sampler, Rhizosphere Research Products) connected to a peristaltic pump and glass syringes. The Rhizons with a filter pore diameter of $0.1 \mu \mathrm{m}$ were horizontally inserted into the cores per 1-cm depth interval through predrilled holes that were sealed with diffusion-tight tape before coring. The extracted pore water was immediately fixed in 5\% ZnAc for sulfate, chloride, and sulfide analyses or in $2 \mathrm{~mol} \mathrm{~L}^{-1} \mathrm{HCl}$ for analyses of dissolved iron. Samples for DIC were fixed in $\mathrm{HgCl}_{2}$ and stored at $4{ }^{\circ} \mathrm{C}$ without gas bubbles in glass vials with an additional butyl layer.

After pore-water extraction, the remaining sediment was immediately cut in sections of $1-\mathrm{cm}$ (depth interval $1-10 \mathrm{~cm}$ ) or 2-cm (depth below $10 \mathrm{~cm}$ ) slices and frozen at $-20^{\circ} \mathrm{C}$ in nitrogen-flushed sampling bags. Before freezing, subsamples for porosity and elemental sulfur analyses were taken. For analysis of elemental sulfur, about $0.2 \mathrm{~g}$ of sediment from each depth interval was put in $0.5 \mathrm{~mL} 5 \% \mathrm{ZnAc}$; $9.5 \mathrm{~mL}$ of methanol was added, and the mixture was vortex mixed. The samples were placed on a shaker for $\sim 12 \mathrm{~h}$, decanted, and transferred to glass vials.

Microscopy and determination of internally stored nitrate and sulfur-Microscopic imaging of the filaments obtained from the whitish bacterial mats exclusively showed cells resembling the morphologically conspicuous genus Beggiatoa (Teske and Nelson 2006). The further classification by $16 \mathrm{~S}$ rRNA gene-based phylogenetic analysis is underway (S. Grünke pers. comm.). To evaluate the role of Beggiatoa in the environment, the morphology of the filaments and the internal storage capacity of substrates were assessed. Between 139 and 161 filaments were picked 
Table 1. List of samples from all targeted habitats. Samples from measurements and experiments are labeled according to the PANGAEA database, in which the geochemical data are deposited (http://www.pangaea.de, doi: 10.1594/PANGAEA.715022). Included are investigations during the Pourquoi pas? cruise 2006 (VKG), the L'Atalante cruise 2005 (ATL05/02-3), and the Polarstern cruise 2003 (PS64). Sediment was sampled either by a multiple corer (MTB-No.) or with push cores (PC-No., PUC-No.). In addition, in situ deployments of the microprofiler (MIC) are included.

\begin{tabular}{|c|c|c|}
\hline Habitat & Measurements & PANGAEA database event label \\
\hline Hot center & $\mathrm{MIC}$ & VKGD278/MIC-9 \\
\hline \multirow{5}{*}{ Warm center } & MIC & VKGD277/MIC-4 \\
\hline & Geochemistry & VKGD276/PC-7, VKGD276/PC-8 \\
\hline & Sulfate reduction & PS64/377/PUC-1, PS64/377/PUC-2 \\
\hline & Nitrate uptake & VKGD276/PC-8 \\
\hline & S-isotopes & VKGD276/PC-8 \\
\hline \multirow[t]{6}{*}{ Beggiatoa } & $\mathrm{MIC}$ & VKGD277/MIC-5 \\
\hline & Geochemistry & VKGD276/PC-11, VKGD276/PC-12, VKGMTB6 \\
\hline & Sulfate reduction & VKGD276/PC-2, VKGD276/PC-13,VKGMTB6 \\
\hline & Nitrate uptake & ATL05/02-3/PUC-26, VKGD276/PC-1, VKGD276/PC-9, VKGD276/PC-4 \\
\hline & S-isotopes & VKGD276/PC-12 \\
\hline & Microscopy, biology & $\begin{array}{l}\text { ATL05/02-3/PUC-14, ATL05/02-3/PUC-15, ATL05/02-3/PUC-24, ATL05/ } \\
\text { 02-3/PUC-23, VKGD276/PC-1, VKGD276/PC-3, VKGD276/PC-3 }\end{array}$ \\
\hline \multirow{2}{*}{ Next to Beggiatoa } & $\mathrm{MIC}$ & VKGD277/MIC-6 \\
\hline & Geochemistry & VKGD276/PC-5, VKGD276/PC-6 \\
\hline \multirow[t]{6}{*}{ Gray mat } & $\mathrm{MIC}$ & VKGD278/MIC-7, VKGD278/MIC-8 \\
\hline & Geochemistry & VKGD277/PC-7, VKGD277/PC-8 \\
\hline & Sulfate reduction & VKGD277/PC-1, VKGD277/PC-3 \\
\hline & Nitrate uptake & VKGD277/PC-7 \\
\hline & S-isotopes & VKGD277/PC-7 \\
\hline & Microscopy & VKGD277/PC-8 \\
\hline Next to gray mat & $\mathrm{MIC}$ & VKGD278/MIC-10 \\
\hline
\end{tabular}

from four cores of the Beggiatoa habitat. The average biovolume and biomass of the filaments were calculated from their length and radius, assuming a cylindrical shape of the organisms. The filaments were transferred to vials with $250 \mu \mathrm{L}$ of demineralized water and immediately frozen at $-20^{\circ} \mathrm{C}$. This procedure breaks the cells and releases the vacuolar nitrate, which was measured after reduction to $\mathrm{N}_{2}$ with a gas chromatograph-mass spectrometer (Hinck et al. 2007). Elemental sulfur was extracted from subsamples with methanol and analyzed as described below. In addition, sediment densely covered with Beggiatoa filaments was vertically sampled in high

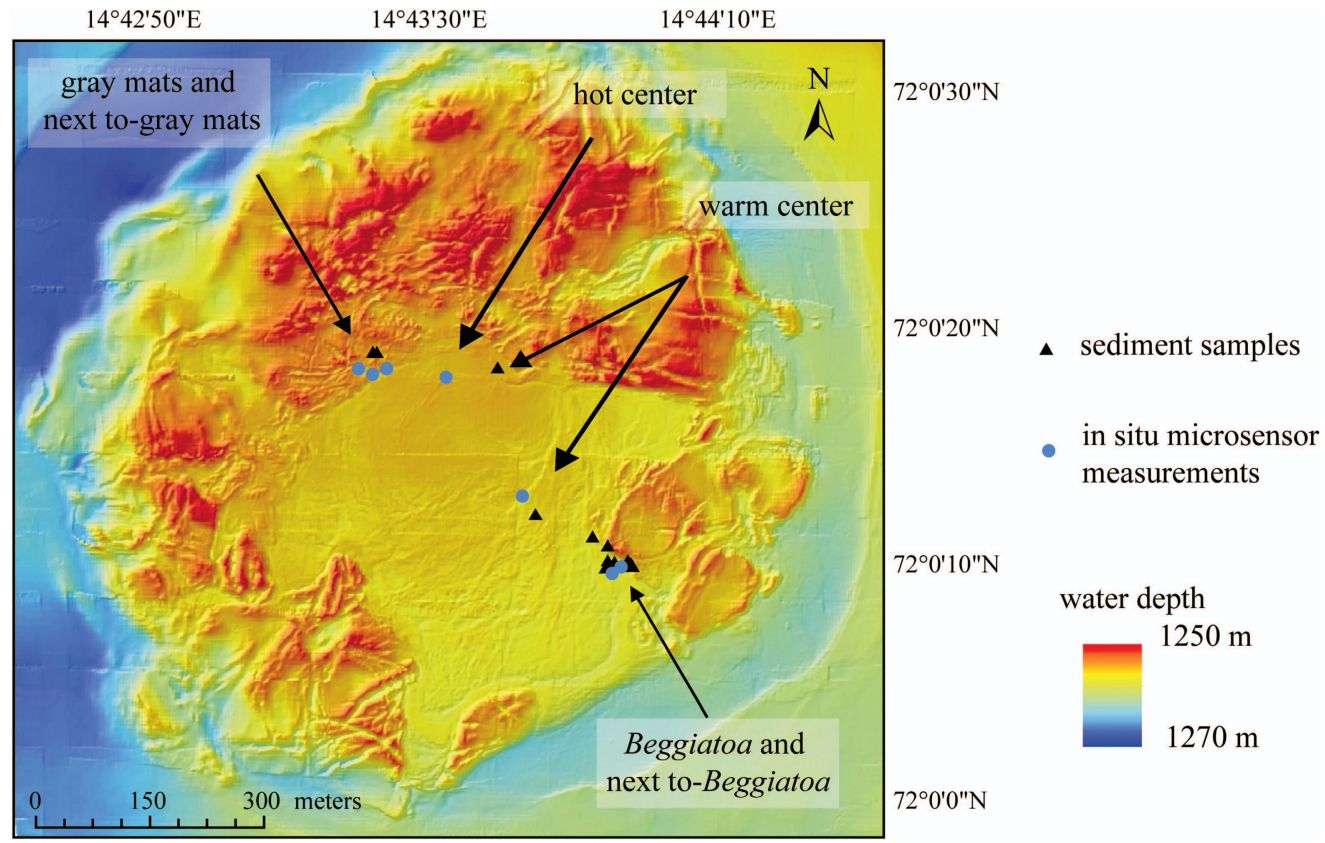

Fig. 1. Map of the Håkon Mosby Mud Volcano showing the sampling and measurement positions in the different habitats. The topographic map was generated during the ARK XIX/3b cruise by Ifremer, Brest (Foucher et al. 2009). 
resolution and frozen, and the nitrate content was measured as described below.

Solid phase geochemistry-Different iron and sulfur solid phase species were identified and quantified. Elemental sulfur was determined on the methanol extracts of biological and sediment samples by high-performance liquid chromatography (Zopfi et al. 2004). The concentrations of acid volatile sulfides (AVS: FeS, some greigite) and chromium reducible sulfur $\left(\mathrm{CRS}\right.$ : $\mathrm{FeS}_{2}, \mathrm{~S}^{0}$, remaining greigite) were assessed with the modified two-step acid distillation method (Fossing and Jørgensen 1989). In the following, AVS and CRS will be referred to as their main components, FeS and pyrite $\left(\mathrm{FeS}_{2}\right)$, respectively. Iron was extracted with the dithionite method (Canfield 1989) and the ascorbic acid method (Ferdelman et al. 1991). The dithionite method extracts amorphous iron oxides, crystalline iron oxides, some iron-bearing silicates, and some AVS (Canfield 1989; Kostka and Luther 1994). Triplicate samples of frozen sediment were extracted in $10 \mathrm{~mL}$ dithionite solution (0.5 $\mathrm{g} \mathrm{L}^{-1}$ sodium dithionite in $0.35 \mathrm{~mol} \mathrm{~L}^{-1}$ acetate/ $0.2 \mathrm{~mol} \mathrm{~L}^{-1}$ sodium citrate) on a shaker for $48 \mathrm{~h}$ at room temperature, and the extracts were filtered afterwards. The extracts were left for at least $72 \mathrm{~h}$ to oxidize the remaining dithionite and were then analyzed with the Ferrozine method (see below) with $1 \%(\mathrm{w} / \mathrm{v})$ hydroxylamine hydrochloride as reducing agent. To determine the amount of dithionitesoluble manganese, subsamples of the same extracts were measured with a Perkin Elmer 3110 flame atomic absorption spectrophotometer. The ascorbic acid method extracts the most reactive, amorphous iron oxides, some AVS and some iron bound in clay minerals (Kostka and Luther 1994). Triplicates of frozen sediment samples were extracted in $10 \mathrm{~mL}$ solution (10 g sodium citrate; $10 \mathrm{~g}$ sodium bicarbonate; $4 \mathrm{~g}$ ascorbic acid in $200 \mathrm{~mL}$ anoxic, demineralized water, adjusted to $\mathrm{pH} 8$ ). Samples were shaken at $60^{\circ} \mathrm{C}$ for $24 \mathrm{~h}$ and then filtered, and iron concentrations were measured with the Ferrozine method (see below).

Pore-water geochemistry-Sulfate and chloride concentrations were measured by non-suppressed anion exchange chromatography (Waters IC-Pak anion exchange column, Waters 430 Conductivity detector). As eluent, isophthalic acid ( $\left.1 \mathrm{mmol} \mathrm{L}^{-1}, \mathrm{pH} 4.6\right)$ containing $10 \% \mathrm{v} / \mathrm{v}$ methanol with a constant flow rate of $1 \mathrm{~mL} \mathrm{~min}^{-1}$ was used. Total dissolved sulfide concentrations $\left(\mathrm{H}_{2} \mathrm{~S}+\mathrm{HS}^{-}+\mathrm{S}^{2-}\right)$ were determined with the diamine complexation method (Cline 1969). For the determination of dissolved iron, Ferrozine was used $\left[1 \mathrm{~g} \mathrm{~L}^{-1}\right.$ Ferrozine in $50 \mathrm{mmol} \mathrm{L}^{-1}$ 4-(2-hydroxyethyl)-1-piperazineethanesulfonic acid (HEPES) buffer, adjusted to $\mathrm{pH}$ 7], and the concentrations were measured spectrophotometrically (Stookey 1970). DIC concentrations were assessed by flow injection (Hall and Aller 1992) with $30 \mathrm{mmol} \mathrm{L}^{-1} \mathrm{HCl}$

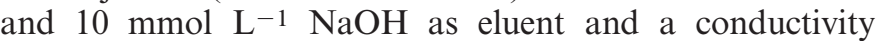
detector (Van Waters and Rogers Scientific, model 1054).

Microsensor measurements and fluxes-High-resolution in situ microsensor measurements were carried out with a deep-sea microprofiler, as described previously (Wenzhöfer et al. 2000; see Fig. 2a). The ROV Victor was used to
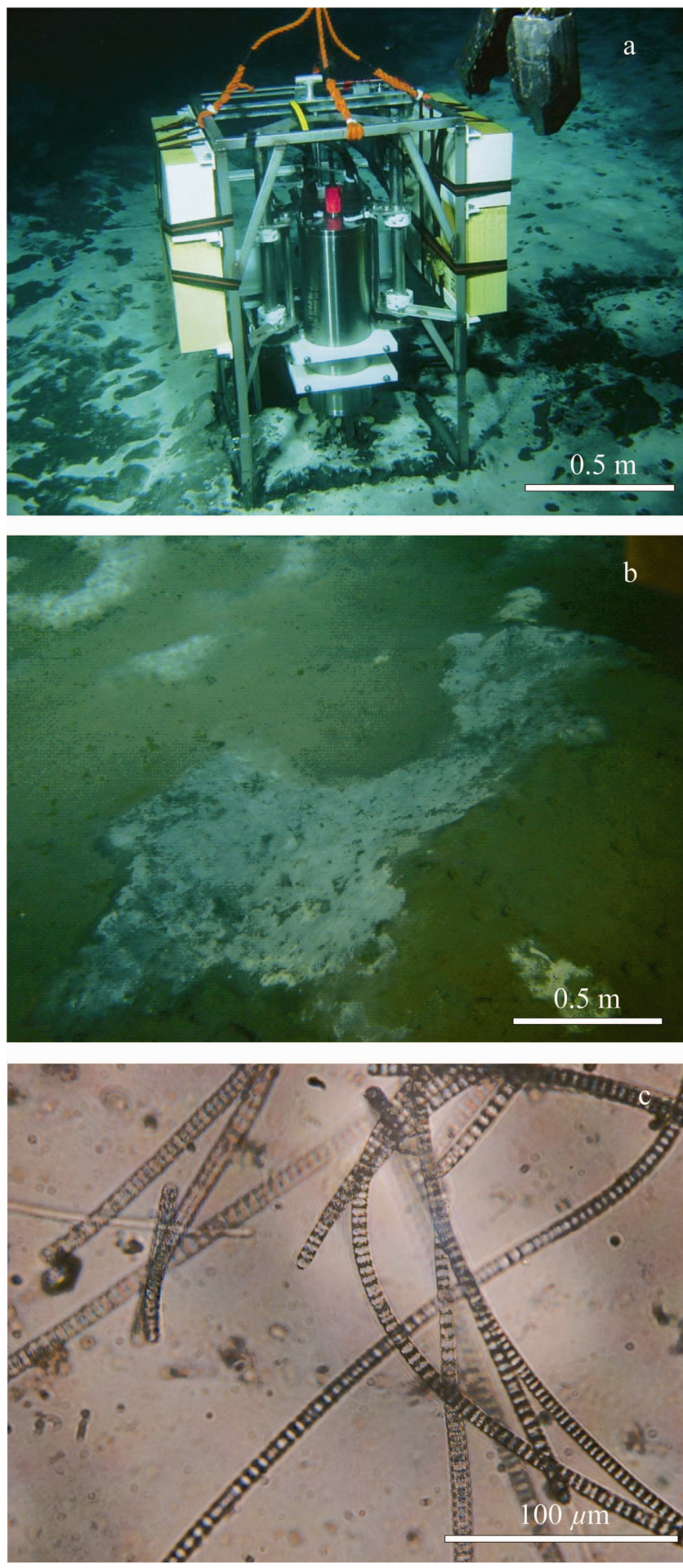

Fig. 2. (a) Microprofiler unit standing on a dense mat of thiotrophic bacteria in the Beggiatoa habitat (source: Ifremer, Victor 6000); (b) gray mat patch prior to the deployment of the microprofiler (source: Ifremer, Victor 6000); and (c) light microscopy image of Beggiatoa-like bacterial filaments from the white thiotrophic mats at Håkon Mosby Mud Volcano habitat. 
precisely position the microprofiler, to start the autonomous profiling routine, and for the instrument retrieval. The microsensors were stepwise driven from the water phase into the sediment to a depth of up to $8 \mathrm{~cm}$. On the profiler electronic unit three $\mathrm{pH}$ microsensors, three oxygen microsensors, two sulfide microsensors (Revsbech and Ward 1983; Jeroschewski et al. 1996; de Beer et al. 1997), and one temperature sensor (3-mm diameter, Pt100, Umweltsensorentechnik $\mathrm{GmbH}$ ) were mounted and calibrated on board the ship, as described previously (Wenzhöfer et al. 2000; de Beer et al. 2006).

In this study altogether seven total deployments of the profiler were carried out at the center habitat, the Beggiatoa habitat, and at the gray mat site of the Håkon Mosby Mud Volcano (Fig. 1; Table 1). Measurements "next to Beggiatoa" were conducted within $\sim 1 \mathrm{~m}$ of a large Beggiatoa mat; "next to gray mat" measurements were conducted $20 \mathrm{~cm}$ away from a gray mat patch. As the surface was sometimes slightly undulating, the tilt of the profiler was estimated by image analyses and used to determine the position of the sediment surface.

Solute fluxes were calculated according to Fick's first law of diffusion, assuming steady-state conditions. Oxygen fluxes were calculated from the oxygen gradients through the diffusive boundary layer according to the method of Jørgensen and Revsbech (1985), thus

$$
\mathrm{J}=\mathrm{D} \frac{\mathrm{dc}}{\mathrm{dz}}
$$

where $\mathbf{J}=$ flux $\left(\mathrm{mmol} \mathrm{m}^{-2} \mathrm{~d}^{-1}\right), \mathbf{D}=$ diffusion coefficient in water $\left(\mathrm{m}^{2} \mathrm{~d}^{-1}\right)$ corrected for temperature and salinity (Li and Gregory 1974), and $\frac{\mathrm{dc}}{\mathrm{dz}}=$ concentration gradient (dc $\left.\left[\mathrm{mmol} \mathrm{m} \mathrm{m}^{-3}\right] ; \mathrm{dz}[\mathrm{m}]\right)$. Sulfide fluxes were calculated from gradients in the sediment according to the following equation:

$$
\mathrm{J}=\phi \mathrm{D}_{\mathrm{Sed}} \frac{\mathrm{dc}}{\mathrm{dz}}
$$

where $\phi=$ porosity and $\mathrm{D}_{\text {Sed }}=$ diffusion coefficient in the sediment $\left(\mathrm{m}^{2} \mathrm{~d}^{-1}\right)$. The diffusion coefficient $\mathrm{D}_{\text {Sed }}$ in the sediment was calculated according to the method of Iversen and Jørgensen (1993):

$$
\mathrm{D}_{\mathrm{Sed}}=\frac{\mathrm{D}}{1+3(1-\phi)}
$$

The diffusion coefficient D at a salinity of $35 \%$ and a temperature of $0^{\circ} \mathrm{C}$ was calculated to be $9.1 \times 10^{-5} \mathrm{~m}^{2} \mathrm{~d}^{-1}$ (Unisense Table, Seawater and Gases) for oxygen and of 6.9 $\times 10^{-5} \mathrm{~m}^{2} \mathrm{~d}^{-1}$ for sulfide (Li and Gregory 1974). Calculated diffusive in situ fluxes were corrected for advective upflow according to the method of de Beer et al. (2006).

Fluxes of advected dissolved iron was calculated as

$$
\mathrm{J}=\mathrm{v} \mathrm{c}
$$

where $\mathrm{v}$ is the fluid upflow velocity $\left(\mathrm{m} \mathrm{d}^{-1}\right)$ and $\mathrm{c}$ is the concentration of the solute in the advected fluid. Fluid upflow velocities, $v$, of the different habitats can be found in de Beer et al. (2006) and in this paper.
Sulfate reduction - Sulfate reduction (SR) was measured by the ex situ whole core injection method according to Jørgensen (1978), adapted as in Treude et al. (2003). On board $5-10 \mu \mathrm{L}$ of $35 \mathrm{SO}_{4}^{2-}$ (dissolved in water, $50 \mathrm{kBq}$ ) radioactive tracer was injected into replicate subcores in depth intervals of $1 \mathrm{~cm}$. Subcores were incubated in the dark at in situ temperature for $24 \mathrm{~h}$. To stop the incubation, the sediment was sliced in 1-cm sections and fixed in $20 \mathrm{~mL}$ $20 \% \mathrm{ZnAc}$. Rates were determined with the single-step cold distillation method (Kallmeyer et al. 2004). It was previously shown that ex situ rates of SR and AOM obtained by whole core injection occur in a ratio of approximately 1 to 1 (fig. 3 of Niemann et al. 2006). In situ measured sulfide fluxes by microsensor measurements are more accurate than ex situ SR (Niemann et al. 2006) and are used here to estimate microbial AOM.

Stable sulfur isotope analyses of AVS and CRS-To determine potential sinks of reduced sulfide, subsamples of precipitated $\mathrm{ZnS}$ from the AVS and CRS distillations were filtered through $0.2-\mu \mathrm{m}$ cellulose nitrate filters and converted to $\mathrm{Ag}_{2} \mathrm{~S}$ in a $0.1 \mathrm{~mol} \mathrm{~L}^{-1} \mathrm{AgNO}_{3}$ solution. The $\mathrm{Ag}_{2} \mathrm{~S}$ precipitates were dried, weighed, and mixed with approximately $3.5 \mathrm{mg}$ vanadium pentoxide in tin cups. The stable sulfur isotope composition of the samples was determined by isotope ratio mass spectrometry using a Eurovector elemental analyzer connected to a Finnigan Delta Plus gas isotope mass spectrometer via a Finnigan Conflo II split interface. Sulfur isotope compositions were determined for the center area, the Beggiatoa habitat, and the gray mat site. Isotopic ratios are displayed in the standard $\delta$ notation $\left(\delta^{34} \mathrm{~S}\right)$ with respect to the Vienna Canyon Diablo Troilite (V-CDT). The accuracy and precision of the isotope mass spectrometer were tested after every 10th sample using international atomic energy agency standard S2 $\left(\delta^{34} \mathrm{~S}\right.$ $20.3 \%$ vs. V-CDT). Standard deviation based on all replicates was $0.4 \%$.

Nitrate uptake - Defined amounts of nitrate were added to the overlying water of retrieved sediment cores. The water column was gently stirred with an air flow. Water samples were taken after different time intervals, acidified, and stored at $4{ }^{\circ} \mathrm{C}$. Nitrate concentrations were measured with a chemiluminiscence NOx analyzer (Thermo Environmental Instruments) based on reduction of $\mathrm{NO}_{2}^{-}$and $\mathrm{NO}_{3}^{-}$and reoxidation of the produced $\mathrm{NO}$ by ozone $\left(\mathrm{O}_{3}\right)$ (Braman and Hendrix 1989). Random samples were checked for nitrite. No nitrite was detected, and all NOx was assumed to be $\mathrm{NO}_{3}^{-}$.

Biomass calculations-Biomass yields of the three different functional groups, sulfide oxidizers (dominated by Beggiatoa) and aerobic and anaerobic methanotrophs, were calculated for the different habitats. Marine chemolithotrophic Beggiatoa gain a biomass of 8.4 15.9 g dry weight per mole sulfide oxidized, corresponding to $0.35-0.66 \mathrm{~mol} \mathrm{C}$ per mole sulfide oxidized, assuming that $50 \%$ of the dry weight is carbon (Nelson et al. 1986; Hagen and Nelson 1997). Beggiatoa biomass yield was assumed to be the same for growth on oxygen 
Table 2. General morphology and characteristics of Beggiatoa filaments picked from the surface mat of four different cores of the Beggiatoa habitat (ATL05/02-3/PUC-14, PUC-15, PUC-24, and PUC-23); samples were taken in two different Beggiatoa patches close to each other.

\begin{tabular}{|c|c|c|c|c|c|c|}
\hline & Length (mm) & Radius (mm) & Biovolume (L) & Biomass $(\mu \mathrm{g})$ & $\begin{array}{l}\text { Internal S } \mathrm{S}^{0} \\
\left(\mathrm{mmol} \mathrm{L} \mathrm{L}^{-1}\right)\end{array}$ & $\begin{array}{l}\text { Internal nitrate } \\
\quad\left(\mathrm{mmol} \mathrm{L}^{-1}\right)\end{array}$ \\
\hline $\begin{array}{l}n_{\text {cores }}=4 \text { with } \\
n_{\text {filaments }}= \\
139-161\end{array}$ & $\begin{array}{c}1.33 \\
( \pm 0.26)\end{array}$ & $\begin{array}{c}4.8 \times 10^{-3} \\
\left( \pm 0.5 \times 10^{-3}\right)\end{array}$ & $\begin{array}{c}1.02 \times 10^{-10} \\
\left( \pm 0.3 \times 10^{-10}\right)\end{array}$ & $\begin{array}{c}0.09 \\
( \pm 0.05)\end{array}$ & $\begin{array}{l}\text { Minimum: } 45 \\
\text { Maximum: } 289 \\
\text { Average: } 120( \pm 113)\end{array}$ & $\begin{array}{l}\text { Minimum: } 73 \\
\text { Maximum: } 149 \\
\text { Average: } 110( \pm 36)\end{array}$ \\
\hline
\end{tabular}

or nitrate. To estimate growth yield from anaerobic oxidation of methane, we assumed that the measured in situ sulfide flux is produced exclusively by AOM. Growth yield from AOM is 0.02 mol $\mathrm{C}$ fixed per mole methane oxidized (Nauhaus et al. 2007). For estimating growth yield of aerobic methanotrophs, we used the oxygen flux measurement from the center and the stoichiometric yield for growth obtained by Leak and Dalton (1986), who measured approximately $8 \mathrm{~g}$ dry weight $(0.33 \mathrm{~mol} \mathrm{C})$ growth yield per mole methane oxidized through the aerobic pathway for mesophilic methanotrophs. We calculated the biomass production from the molar yields and the in situ measured fluxes of sulfide (in case of sulfide oxidation and AOM) or oxygen (in case of aerobic methane oxidation) in the particular habitat. By multiplying these results with the area of the habitat, the biomass gain per habitat in 1 yr was calculated. For this calculation an area of the Beggiatoa habitat of $30,000 \mathrm{~m}^{2}$ (visual observations, adapted from Jerosch et al. 2007) was used. The center was separated into a 'hot center' of about $14,000 \mathrm{~m}^{2}$, as estimated from visual observations and temperature measurements (Feseker et al. 2008), and a residual 'warm center' of about 101,000 m² $\left(115,000 \mathrm{~m}^{2}\right.$ for the total center area; Jerosch et al. 2007).

\section{Results}

Characteristics of the different habitats-To study the effect of methane fluxes and upflow velocities on biological vs. geochemical sulfide conversions, we concentrated our study on three main habitats: the center site, the Beggiatoa habitat, and the gray mat fields.

Sediments in the center area were devoid of macrofauna and microbial mats. Based on visual observations and previous temperature measurements (Feseker et al. 2008) we differentiated between the hot center in the north of the central area (Fig. 1), with a few sites of methane bubble release, disturbed sediments, and small cracks at the sediment surface. Southeast of this hot center, the seafloor showed a slightly undulating surface littered with small holes (diameter, $2 \mathrm{~cm}$ ). In this warm center no gas bubble escape was observed.

Sediments covered with white mats were sampled southeast of the center (Fig. 1) in an area with a dense mat of 1-2 $\mathrm{mm}$ in thickness. The mats extended for hundreds of meters, with patches of large uncovered sediment of several centimeters to decimeters (Fig. 2a). The mats are mainly composed of one type of filamentous bacterial cells, identified by light microscopy as a member of the genus Beggiatoa (Fig. 2c). Some Beggiatoa filaments reached a few millimeters into the sediment, but most filaments were present in the mat covering the sediment surface. Beggiatoa filaments had an average length of $1.3 \mathrm{~mm}$ and an average filament radius of $4.8 \mu \mathrm{m}$, resulting in a biovolume of $1.02 \times 10^{-10} \mathrm{~L}$ per filament. Filaments contained on average $120 \mathrm{mmol} \mathrm{L}^{-1}$ elemental sulfur and 110 mmol $\mathrm{L}^{-1}$ nitrate (Table 2). In sediments densely covered with Beggiatoa, a high total (internal cellular pool plus pore water) nitrate content of on average $0.3 \mathrm{mmol} \mathrm{L}-1$ was measured in the uppermost $1.6 \mathrm{~mm}$. This mainly originated from internally stored nitrate released after freezing and thawing and subsequent centrifugation. Below $1.6 \mathrm{~mm}$ the total nitrate content decreased rapidly (Fig. 3a). Beggiatoa-covered sediments, incubated at in situ temperature, lost all nitrate in the upper $2 \mathrm{~cm}$ of the sediment within $6 \mathrm{~d}$ (Fig. 3b).

Patches of gray mats of $0.5-5 \mathrm{~m}$ in diameter (Fig. 2b) occurred in a transition zone northwest of the mud volcano center or within the hummocky area of the Håkon Mosby Mud Volcano in patches devoid of tubeworms. Often a gray mat was surrounded or partially covered by a white mat. At the seafloor some of the mats appeared quite thick and gelatinous, but in all retrieved cores the average mat thickness was only approximately $1 \mathrm{~mm}$. Microscopy showed a morphologically highly diverse community, as described previously (de Beer et al. 2006).

None of the sediment cores from the different habitats showed a visible color transition associated with redox

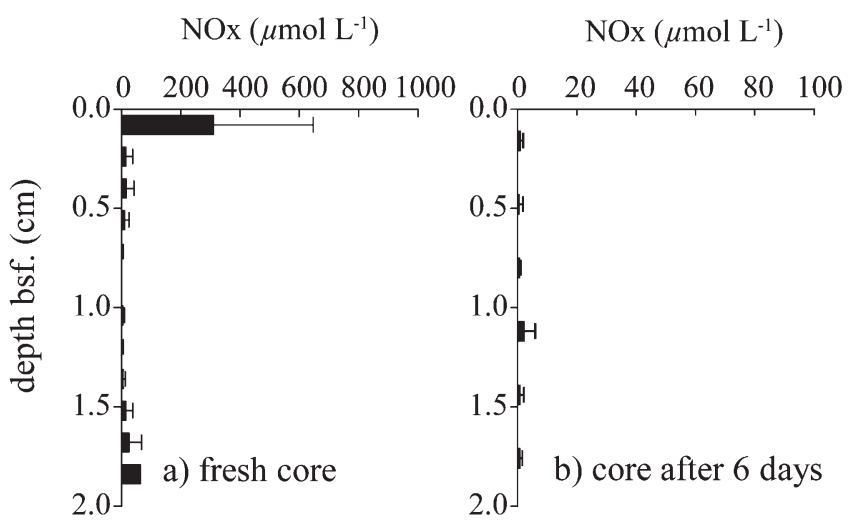

Fig. 3. Distribution of the total nitrate content in (a) a fresh sediment core densely covered with Beggiatoa filaments and (b) a sediment core covered with Beggiatoa filaments that stood for $6 \mathrm{~d}$ at in situ temperature; total nitrate content $=$ pore-water nitrate + nitrate released from disrupted Beggiatoa filaments. Note the different scales. Error bars display the standard error $(n=3)$. 
gradients; the sediment color was typically dark grayish over the entire core length.

Solid phase geochemistry-The results of all measured solid phase parameters are summarized in Fig. 4. Concentrations of dithionite and ascorbic acid-extractable iron, AVS, and CRS were similar in all habitats over the entire core lengths. Only in the sediment under the gray mat was the pyrite (CRS) concentration slightly lower in the top $4 \mathrm{~cm}$, below which it increased to somewhat higher concentrations. In the center site and the gray mat habitat concentrations of FeS (AVS) slightly decreased with depth. The amount of dithionite-extractable manganese in the sediment was below $2 \mu \mathrm{mol} \mathrm{cm} \mathrm{cm}^{-3}$ in all habitats (data not shown). No subsurface peaks of manganese were detected in the surface sediments, indicating the absence of manganese oxides. Clear differences between the habitats were observed in terms of elemental sulfur concentrations and distributions. In the center site and in the next-toBeggiatoa sediments the elemental sulfur levels were less than $0.2 \mu \mathrm{mol} \mathrm{cm}-3$ throughout the core (Fig. 4c,k), whereas they were as high as $0.6 \mu \mathrm{mol} \mathrm{cm}{ }^{-3}$ in the nearsurface sediments of the gray mat and the Beggiatoa site (Fig. 4g,n).

Sulfur (S)-isotope composition-The stable isotope composition of the pyrite (CRS) was similar at the three sites and varied only between $-5 \%$ and $0 \%$, vs. V-CDT, with sediment depth (Fig. 4d,h,o). In contrast, the isotope composition of AVS (FeS) varied strongly. In the top $2 \mathrm{~cm}$ of the gray mat sediments, AVS was enriched in ${ }^{34} \mathrm{~S}(+5 \%$ vs. V-CDT) relative to CRS, but it was relatively depleted at depth ( $-5 \%$ vs. V-CDT). An inverse relationship was observed in the sediments from the center, where AVS was more depleted relative to pyrite at the top but became gradually more enriched with increasing sediment depth (Fig. 4d,h,o). Lastly, in the Beggiatoa-covered sediments, $\delta^{34} \mathrm{~S}_{\mathrm{FeS}}$ was ${ }^{34} \mathrm{~S}$-enriched relative to pyrite throughout the sediment core and varied little with depth.

Pore-water geochemistry-Results from pore-water analyses are summarized in Fig. 5. The sulfate gradients were steeper in the Beggiatoa site (Fig. 5f) than in the warm center and the next-to-Beggiatoa site (Fig. 5a,k). Sulfate concentrations decreased only slightly with depth in gray mat sediments (Fig. 5p). As chloride is not reactive, the steepness of its gradient can be used as a measure for upflow of mud and pore water with different chloride content (Aloisi et al. 2004; Wallmann et al. 2006). The chloride gradients differed only slightly between the warm center, the Beggiatoa, and the next-to-Beggiatoa sediments (Fig. $5 \mathrm{c}, \mathrm{h}, \mathrm{m}$ ). In the top $15 \mathrm{~cm}$ of sediment below the gray mat chloride did not decrease (Fig. 5r). Sulfide concentrations were up to a magnitude lower in the extracted pore water than as measured in situ by microsensor measurements as a result of stripping by degassing methane during retrieval. Below the sulfidic zones (Fig. 5b,g,l) dissolved iron was present (Fig. 5d,i,n). In zones with high sulfide content dissolved iron concentrations sometimes varied, likely as a result of sampling artifacts. DIC pore-water profiles were scattered in the gray mats (Fig. 5t), probably as a result of disturbances by outgassing. In all other habitats DIC increased with depth (Fig. 5e,j,o).

In situ microsensor measurements-The results from the in situ measurements are shown in Figs. 6-8. In the hot center, where only $\mathrm{pH}$ and temperature measurements were successful, temperature increased sharply with depth (Table 3). The steep sediment temperature gradients indicate an upflow of warm fluids from the deeper subsurface. The $\mathrm{pH}$ decreased pronouncedly in the upper $5 \mathrm{~cm}$ (Fig. 6a). The $\mathrm{pH}$ profile in the warm center showed a similar shape, but the decrease with depth was not as strong as in the hot center (Fig. 6b). Oxygen was present in the upper $1.3 \mathrm{~mm}$ of the sediment. Sulfide concentrations were low overall, peaked at $2 \mathrm{~cm}$ in depth, and were below detection below $3 \mathrm{~cm}$ in depth. Sulfide and oxygen profiles overlapped. The temperature gradient was less than $25 \%$ of the hot center temperature gradient (Table 3).

At the Beggiatoa site, oxygen penetration was only $0.5 \mathrm{~mm}$ (Table 4) into the mat and did not reach the sediment. The sulfide profile showed highest concentrations at 2-4 cm. A gap between oxygen and sulfide of nearly $4 \mathrm{~mm}$ was observed (Fig. 7a), as reported previously (de Beer et al. 2006). All three replicate $\mathrm{pH}$ profiles showed a $\mathrm{pH}$ minimum near the mat surface and a $\mathrm{pH}$ maximum at $4 \mathrm{~mm}$ depth. The $\mathrm{pH}$ maximum coincided with the zone where the upward-diffusing sulfide disappeared. This $\mathrm{pH}$ undulation had not before been observed at this site.

In the next-to-Beggiatoa site (Fig. 7b) oxygen penetrated $3.0 \mathrm{~mm}$. This was the deepest oxygen penetration depth measured during our in situ deployments at the Håkon Mosby Mud Volcano and was associated with the lowest temperature gradient. Sulfide and oxygen profiles overlapped. Sulfide concentrations were much lower than in the directly adjacent Beggiatoa-covered sediments. The $\mathrm{pH}$ showed a gradual decrease from the overlying seawater.

Sulfide concentrations were always very high in gray mat sediments, with the steepest gradients near the sediment surface (in Fig. 8a: average sulfide profile of two deployments). Oxygen penetration was comparable to the Beggiatoa-covered sediment, but sulfide and oxygen profiles overlapped. The $\mathrm{pH}$ profile showed a small peak just below the sediment surface; below this the $\mathrm{pH}$ decreased gradually.

In the next-to-gray mat site (Fig. 8b) sulfide reached peak values that were 10 times lower than in the gray matcovered area. The $\mathrm{pH}$ decreased only slightly from seawater values in the upper $6 \mathrm{~cm}$. Oxygen penetrated only $0.3 \mathrm{~mm}$ into the sediment. Temperature gradients in both the gray mat and in the next-to-gray mat sediments were higher than in the Beggiatoa habitat.

Oxygen and sulfide fluxes-The fluxes calculated from in situ microsensor measurements (oxygen flux into the sediment and upward-directed sulfide flux), corrected for upward advection, and the averaged oxygen penetration depths of all assessed habitats are shown in Table 4. Oxygen fluxes were highest in the gray mat habitat, slightly smaller in the next-to-gray mat habitat and the Beggiatoa 

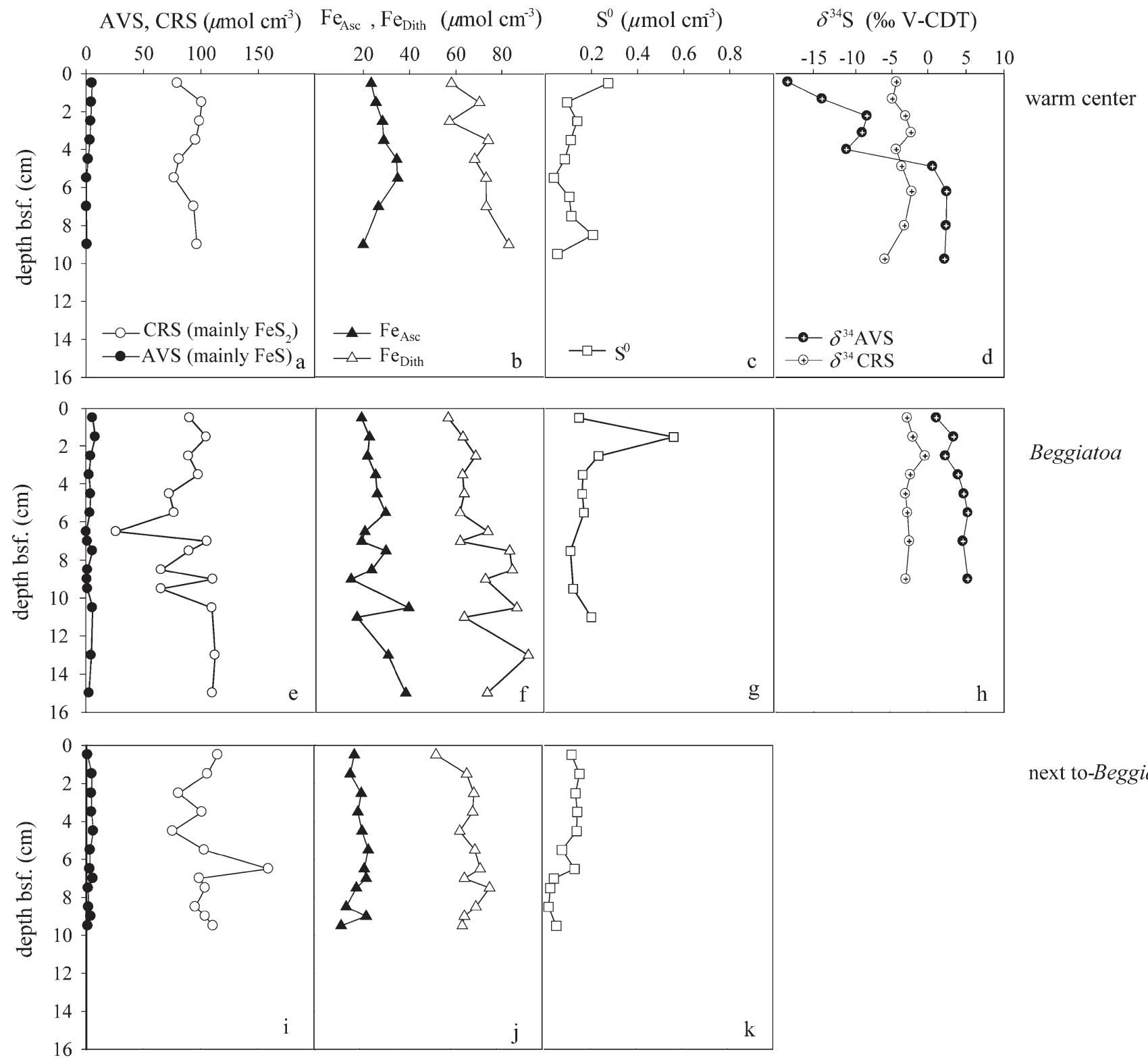

next to-Beggiatoa

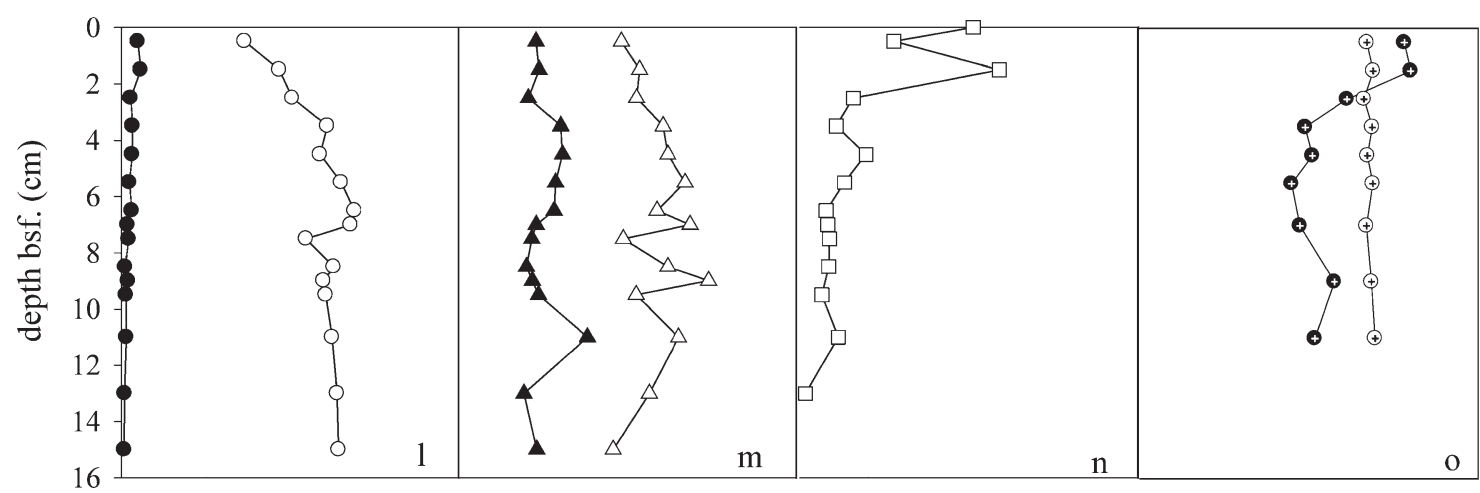

gray mats

Fig. 4. Iron and sulfur geochemistry and S-isotope distribution in the solid phase at different habitats ([a-d] warm center, [e-h] Beggiatoa site, [i-k] next-to-Beggiatoa site, and [1-o] gray mat area); CRS, chromium reducible sulfur $\left(\mathrm{FeS}_{2}, \mathrm{~S}^{0}\right.$, some greigite); AVS, acid reducible sulfide $\left(\mathrm{FeS}\right.$, some greigite); $\mathrm{Fe}_{\mathrm{Asc}}$, ascorbic acid-extractable iron; $\mathrm{Fe}_{\mathrm{Dith}}$, dithionite-extractable iron; $\mathrm{S}^{0}$, elemental sulfur. 


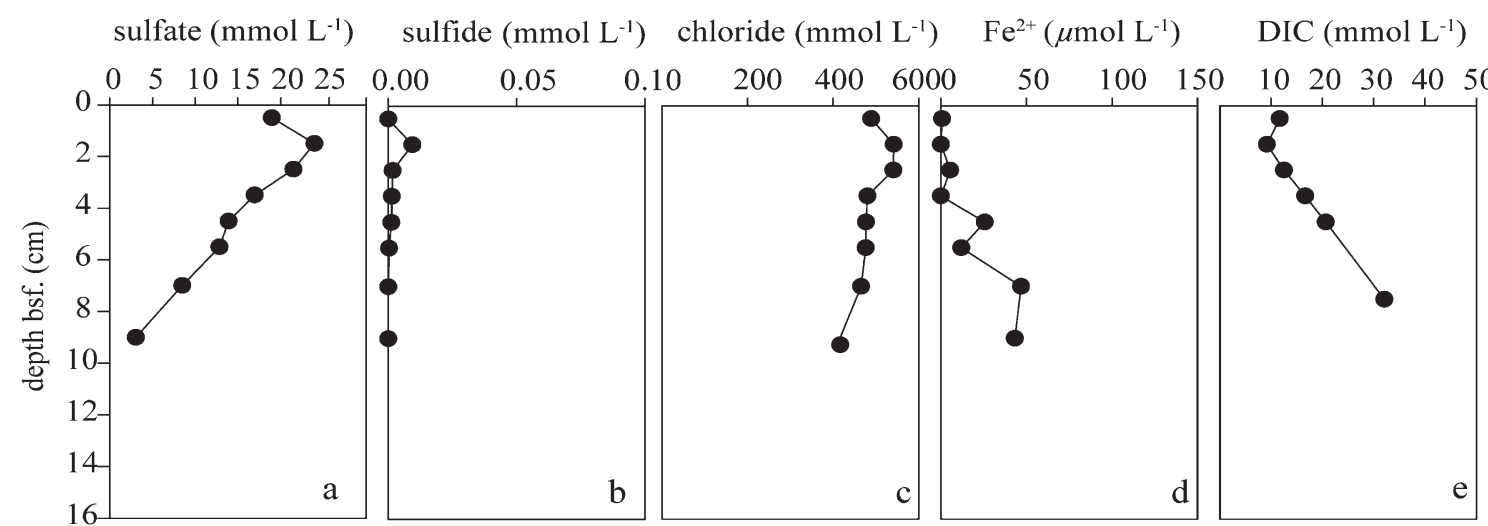

warm center
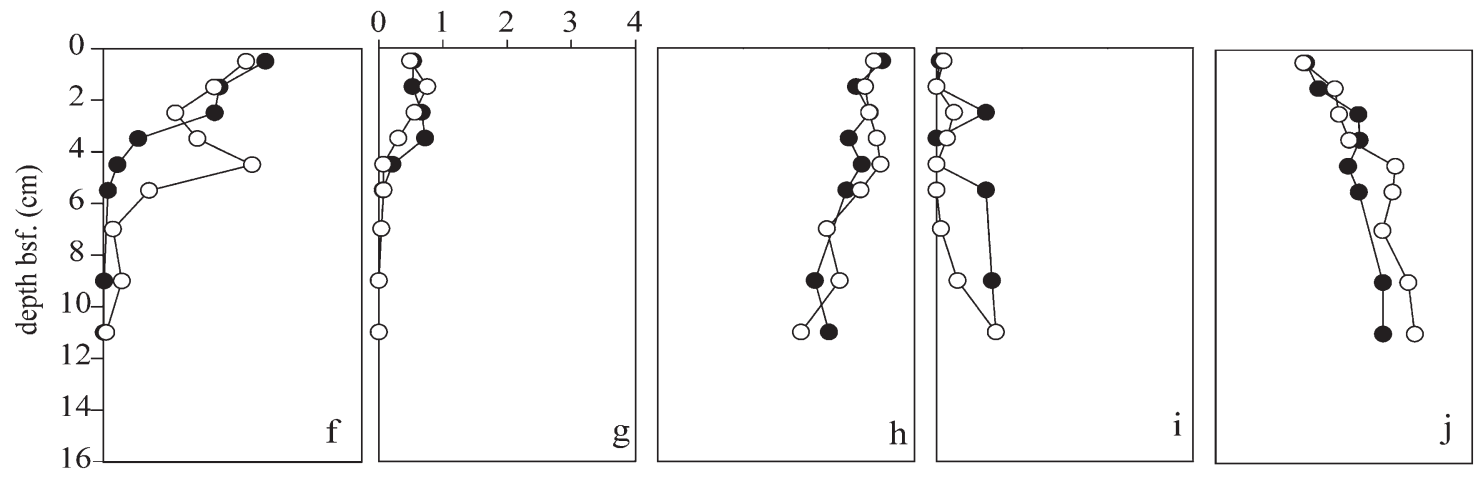

Beggiatoa

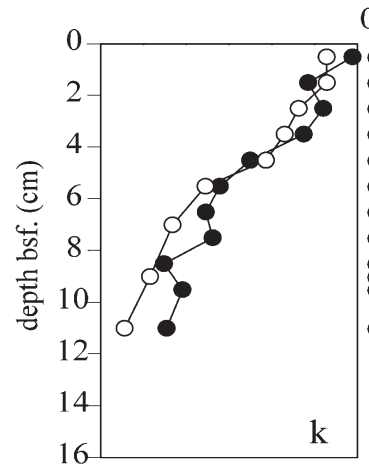

$0.00 \quad 0.05$

0.10

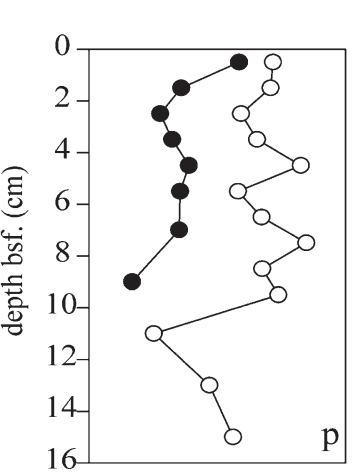

$\begin{array}{lllll}0 & 1 & 2 & 3 & 4\end{array}$
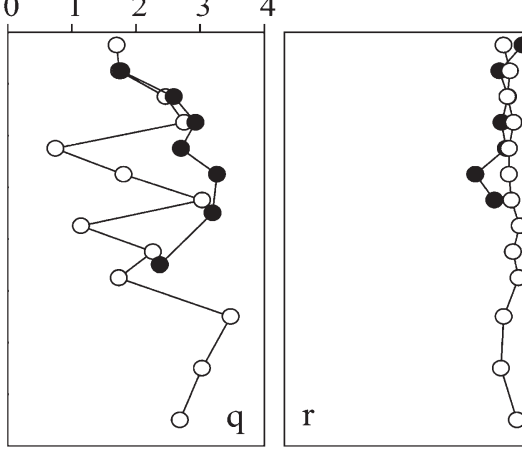

$\mathrm{m}$
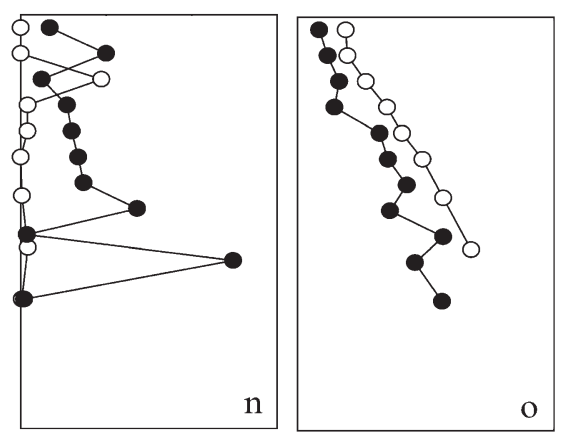

next to-Beggiatoa

Fig. 5. Vertical distribution of sulfate, sulfide, chloride, dissolved iron, and dissolved inorganic carbon (DIC) in the sediments of (ae) the warm center site, $(\mathrm{f}-\mathrm{j})$ the Beggiatoa fields, $(\mathrm{k}-\mathrm{O})$ the next-to-Beggiato site, and $(\mathrm{p}-\mathrm{t})$ the gray mat habitat. Note the different scales for sulfide in the different habitats.

fields, and strongly reduced in the next-to-Beggiatoa site and the warm center sediments. Sulfide fluxes followed a similar trend as those of oxygen, but the lowest were found next to gray mats.
$S R$ rates - SR was measured ex situ on the Beggiatoa habitat, the gray mat site, and the warm center area. In Beggiatoa-covered sediments the highest SR rate, $1200 \mathrm{nmol} \mathrm{cm}^{-3} \mathrm{~d}^{-1}$, occurred in the $1-3$-cm depth interval 


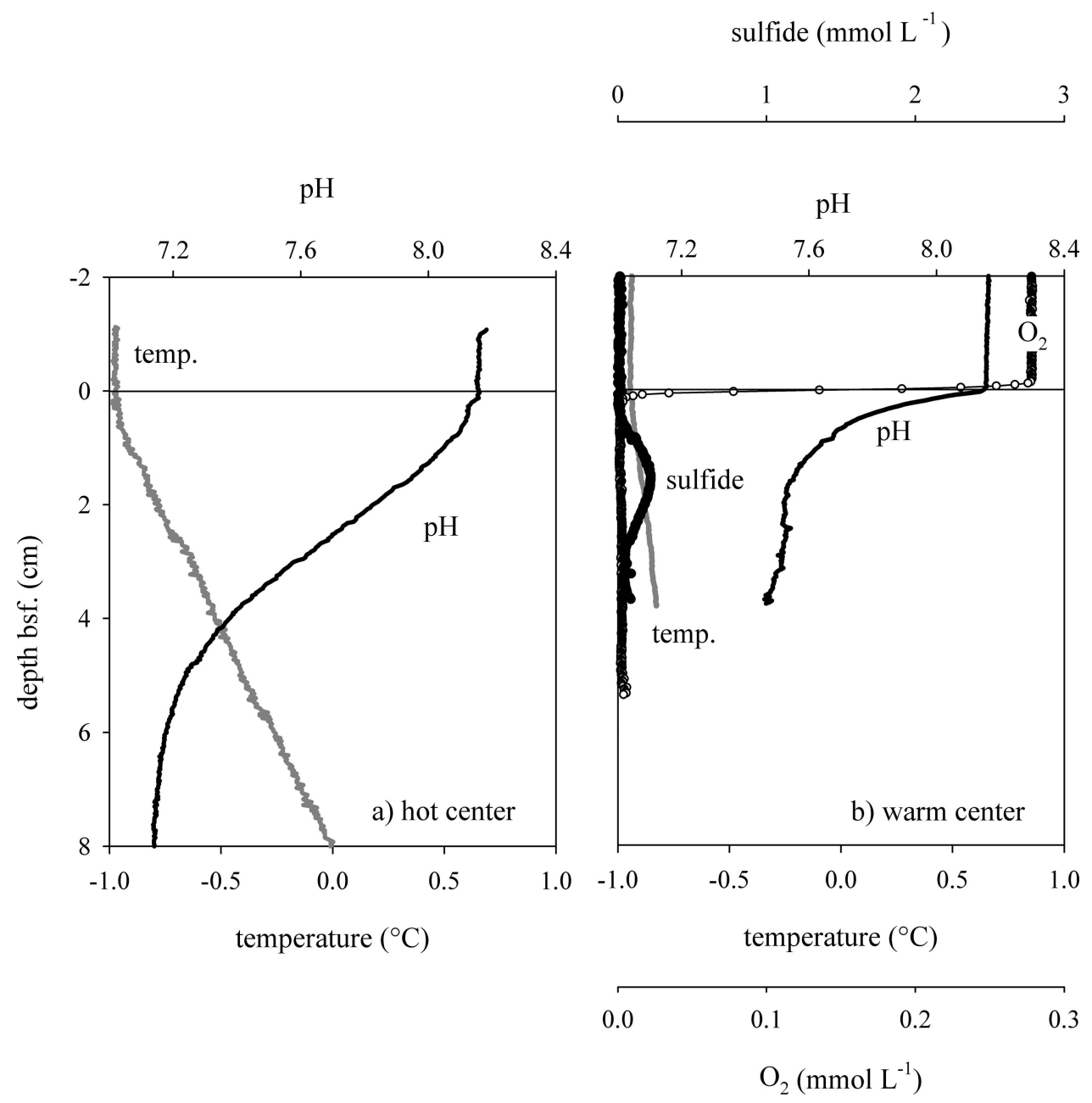

Fig. 6. In situ measured microprofiles in sediments from (a) the hot center and (b) the warm center.

and strongly decreased below $4 \mathrm{~cm}$ depth. In the gray mats SR occurred irregularly in the top $15 \mathrm{~cm}$, with values ranging from 100 to $1400 \mathrm{nmol} \mathrm{cm}-3 \mathrm{~d}^{-1}$. At the center site SR was low, with a maximal value of $20 \mathrm{nmol} \mathrm{cm}^{-3} \mathrm{~d}^{-1}$, and decreased strongly with depth. Integrated SR rates for the upper $10 \mathrm{~cm}$ varied by a factor of 200 between habitats and ranged from only $0.5 \mathrm{mmol} \mathrm{m}^{-2} \mathrm{~d}^{-1}$ in the warm center to $59 \mathrm{mmol} \mathrm{m}^{-2} \mathrm{~d}^{-1}$ in the gray mat (Table 4). Despite the considerable small-scale variability associated with the mat habitats, the average SR rates measured explain very well the average sulfide fluxes measured in situ with the microsensors. At the Håkon Mosby Mud Volcano higher hydrocarbons and organic matter-driven SR are insignificant, and the measured rates can be assigned entirely to AOM (Milkov et al. 2004; Niemann et al. 2006).

Experimental determination of nitrate uptake-Nitrate uptake was higher in Beggiatoa mats than in gray mats and the center sediments (Table 5). The initial uptake rate of starved Beggiatoa was up to eight times higher than after $1 \mathrm{~h}$ of exposure. For the calculation of the nitrate flux the regression of the gradients (Fig. 9) after this initial hour was used. In the Beggiatoa sediments the nitrate uptake rate increased with higher nitrate concentrations in the water overlying the core. Increasing the seawater nitrate concentration 20-30-fold still resulted in constant decline after $66 \mathrm{~h}$ of exposure (Fig. 9). Since the nitrate decrease in the water is caused by both nitrate uptake by bacteria and molecular diffusion of nitrate from the water column into the sediment, the purely diffusional flux at given concentrations and time intervals was modeled (COMSOL multiphysics model) and subtracted from the values calculated from the regression of the gradient. This value then corresponds to the nitrate uptake by bacteria.

\section{Discussion}

At the Håkon Mosby Mud Volcano the presence and absence of thiotrophic mats can be explained by the sulfide fluxes from AOM. High fluxes of sulfide of $>10 \mathrm{mmol} \mathrm{m}^{-2} \mathrm{~d}^{-1}$ are exploited by thiotrophic mats. At sulfide fluxes of $7 \mathrm{mmol} \mathrm{m}^{-2} \mathrm{~d}^{-1}$ and less, these mats do not form (Table 4). The patchiness of the mats can vary on scales of centimeters to $100 \mathrm{~m}$. This indicates a strong spatial heterogeneity in fluid upflow and methane supply to the seafloor and, hence, spatially variable AOM activity. A 


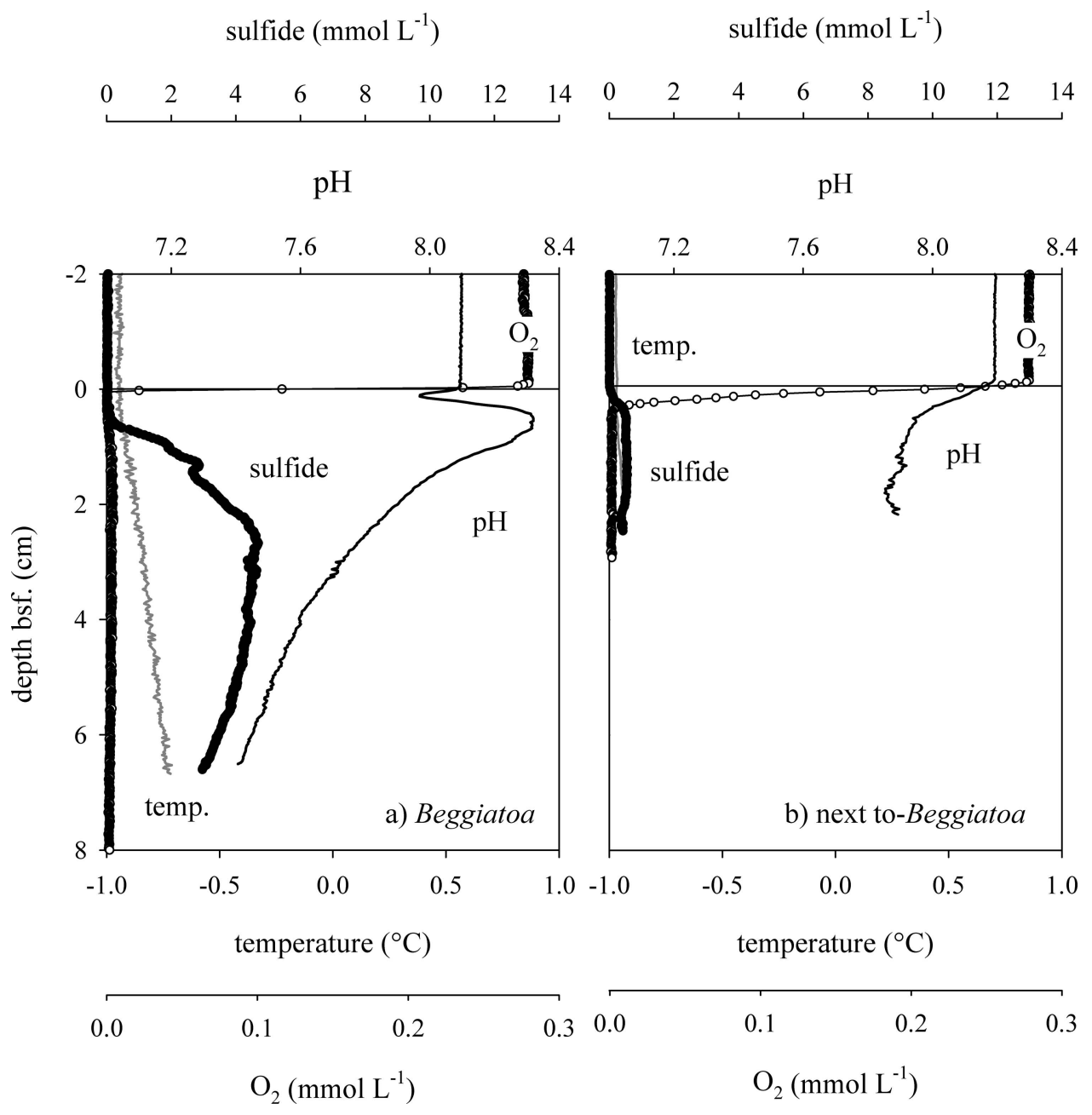

Fig. 7. Sulfide, $\mathrm{pH}$, temperature, and oxygen profiles measured in situ in (a) sediments densely covered with Beggiatoa filaments and (b) in sediments without a visible Beggiatoa mat: next to Beggiatoa.

third possible limitation of thiotrophic primary production could be the competition between geochemical and microbial sulfide oxidation. However, we found bacterial processes to be responsible for both the sulfide production as well as the removal, showing that a substantial fraction of the AOM-associated DIC production is efficiently channeled into chemosynthetic carbon fixation.

Beggiatoa habitat - Sulfide production: SR rate measurements showed that in the Beggiatoa habitat most sulfide formed in the upper $3 \mathrm{~cm}$. Also, the sulfide microprofile indicates a hot spot of AOM at $2-4 \mathrm{~cm}$ below seafloor (Fig. 7a). The averaged depth-integrated SR rate was close to the sulfide flux obtained from the microprofiles (Table 4). Thus, very little sulfide is consumed between the source of the sulfide and the zone of maximal thiotrophic consumption at $4 \mathrm{~mm}$ in depth. Precipitation of iron sulfides is minor, and most of the sulfide is available for consumption by thiotrophic bacteria. To confirm that in the Beggiatoa habitat sulfide oxidation is mainly performed by thiotrophic bacteria, we addressed the questions of whether Beggiatoa are actually capable of oxidizing the total sulfide supply and whether or not, indeed, no geochemical sulfide oxidation is detected from the distribution of the iron minerals in the sediment.

Biological sulfide oxidation: As in situ microsensor measurements in the Beggiatoa habitat showed a pronounced gap between the depths of oxygen depletion and sulfide appearance, direct aerobic sulfide oxidation can be excluded. This characteristic gap was not observed in the other habitats and was likely caused by migrating Beggiatoa via anaerobic oxidation of sulfide with nitrate. At ambient nitrate concentrations the nitrate flux into the Beggiatoa mats was as high as the upward sulfide flux (Tables 4, 5); thus, the nitrate supply was sufficient to consume the total sulfide flux (Eqs. 1 and 2). Beggiatoa stored nitrate up to a concentration of $110 \mathrm{mmol} \mathrm{L}^{-1}$ (Table 2), a measure that is about 7500 -fold higher than the environmental background concentration of $0.015 \mathrm{mmol} \mathrm{L}^{-1}$. From the storage capacity of individual filaments (Table 2) and the total nitrate content in the sediment we calculated that $2.7 \times 10^{4}$ Beggiatoa filaments are present per square centimeter of sediment in the zone with the high nitrate content (Fig. $3 \mathrm{a} ; 0.3 \mathrm{mmol} \mathrm{L}^{-1}$ nitrate $/ 1.12 \times 10^{-8} \mathrm{mmol}$ nitrate per 1 filament). The mat itself (thickness: $1.6 \mathrm{~mm}$ ) hosts $4.2 \times 10^{7}$ Beggiatoa filaments 


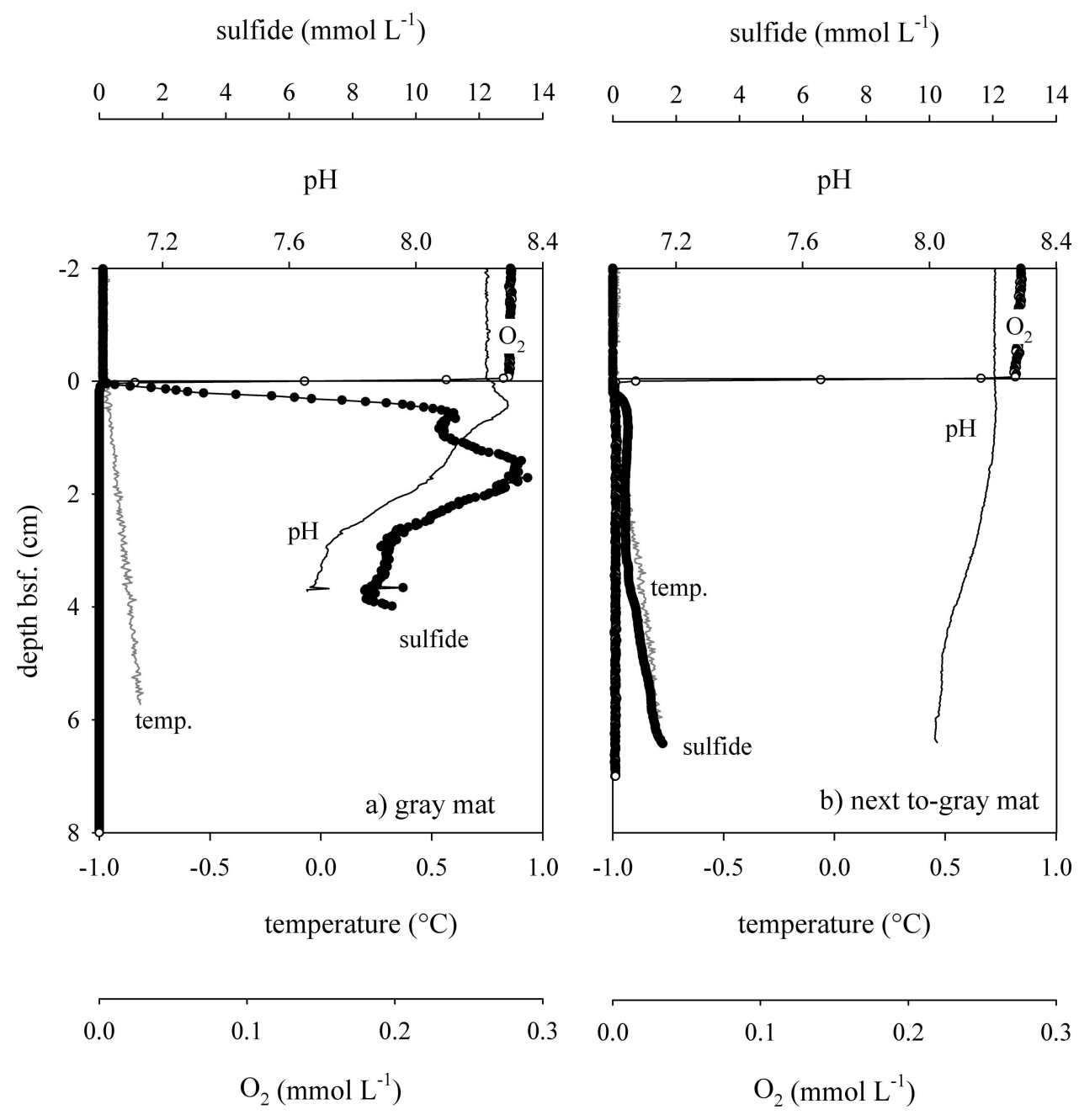

Fig. 8. In situ microprofiles from sediments covered by (a) a gray mat and (b) $20 \mathrm{~cm}$ aside a gray mat: next to gray mat. The sulfide profile in (a) shows an average value gained during two microprofiler deployments.

per square meter. Beggiatoa has a wet biomass of $3.8 \mathrm{~g} \mathrm{~m}^{-2}$ $\left(4.2 \times 10^{7}\right.$ filaments $\mathrm{m}^{-2} \times 9 \times 10^{-8} \mathrm{~g}$ wet weight per filament), corresponding to $0.8 \mathrm{~g} \mathrm{~m}^{-2}$ dry weight, assuming a water content of $80 \%$. All nitrate disappeared from the sediment within $6 \mathrm{~d}$ (Fig. 3b); thus, the vacuolar nitrate decrease was at least $18,000 \mathrm{mmol} \mathrm{m}^{-3} \mathrm{~d}^{-1}\left(110 \mathrm{mmol} \mathrm{L}^{-1 /}\right.$ $6 \mathrm{~d}$ ), similar to a value reported previously (Preisler et al. 2007).

The unique shape of the $\mathrm{pH}$ profile can be caused by sequential sulfide oxidation. Anaerobic sulfide oxidation with nitrate is a proton-consuming process (Eqs. 1 and 2) leading to the observed local $\mathrm{pH}$ increase at around $4 \mathrm{~mm}$ in sediment depth where the upward-diffusing sulfide disappears (Fig. 7a). The $\mathrm{pH}$ minimum located at the lower boundary of the oxic zone can be a consequence of oxidation of $\mathrm{S}^{0}$ to sulfate:

$$
2 \mathrm{~S}^{0}+3 \mathrm{O}_{2}+2 \mathrm{H}_{2} \mathrm{O} \rightarrow 2 \mathrm{SO}_{4}^{2-}+4 \mathrm{H}^{+}
$$

Indeed a high $\mathrm{S}^{0}$ content of $120 \mathrm{mmol} \mathrm{L}-1$ was found in the mat, and, thus, $\mathrm{S}^{0}$ will be the principal electron donor for Beggiatoa in the sulfide-depleted sediment and mat layer. The oxygen flux (Table 4) is high enough to oxidize large amounts of $\mathrm{S}^{0}$ (Eq. 8). When gliding between the oxic and the sulfidic zone, internally stored energy sources (nitrate and $\mathrm{S}^{0}$ ) will be used. Accordingly, the $\sim 0.4$ $\mu \mathrm{mol} \mathrm{cm} \mathrm{cm}^{-3}$ surplus sulfur in the surface sediments will be due to the intracellular sulfur pool of the filaments.

Spatially separated oxidation steps were used to explain $\mathrm{pH}$ microprofiles measured in laboratory-incubated Beggiatoa mats (Sayama et al. 2005; Kamp et al. 2006). However, a series of geochemical reactions can also explain similar $\mathrm{pH}$ profiles. Preisler et al. (2007) reported an intense manganese and iron cycle in methane-containing sediments (Eckernförde Bay, Baltic Sea), in which the chemical oxidation of sulfide with oxidized iron caused an increase in $\mathrm{pH}$. Produced $\mathrm{Fe}^{2+}$ diffuses upward and reduces manganese oxide, and the co-occurring iron oxide precipitation causes a $\mathrm{pH}$ minimum.

Potential role of iron for sulfide oxidation: In the mud volcano fluids $\mathrm{Fe}^{2+}$ is transported upward with a flux of $0.05 \mathrm{mmol} \mathrm{m}^{-2} \mathrm{~d}^{-1}$. Dissolved iron will precipitate near the $\mathrm{AOM}$ zone as $\mathrm{FeS}$ and/or pyrite. However, this process 
Table 3. Temperature gradients measured in situ with the microprofiler.

\begin{tabular}{lc}
\hline \hline \multicolumn{1}{c}{ Habitat } & Temperature gradient $\left({ }^{\circ} \mathrm{C} \mathrm{m}^{-1}\right)$ \\
\hline Hot center & 13.9 \\
Warm center & 3.2 \\
Beggiatoa & 2.8 \\
Next to Beggiatoa & 1.6 \\
Gray mat & $2.8,4.6$ \\
Next to gray mat & 3.2 \\
\hline
\end{tabular}

does not balance the dissolved sulfide flux $\left(\mathrm{J}_{\text {sulfide }}=\right.$ $11.6 \mathrm{mmol} \mathrm{m}-2 \mathrm{~d}^{-1}$; Table 4), which is 230 times higher. The manganese concentration is too low to play a geochemical role in iron or sulfide oxidation. Bioturbating and bioirrigating organisms were absent in all sampled habitats and thus do not drive an iron oxidation and reduction cycle in the suboxic zone.

Potentially reactive dithionite and ascorbic acid-extractable iron remains the only detected species available for sulfide oxidation. Deposition or transport of rising mud from a deep reservoir most likely supplies each habitat with similar iron mineral species. In highly sulfidic environments, more iron sulfide minerals than oxidized iron minerals are expected. Conversely, in habitats with little sulfide or in suboxic habitats, more oxidized iron and a minor amount of iron sulfides would be expected. However, extractions showed similar concentrations of dithionite and ascorbic acid-extractable iron in all habitats investigated here (Fig. 4), which could be the result of a relatively recent mud flow forming the inner flat center area of the Håkon Mosby Mud Volcano. Even the sediments from the warm center that had virtually no free sulfide showed the same solid-phase iron concentrations as the highly sulfidic gray mat sediments. Thus, either the available iron minerals are not reacting or are only slowly reacting or the applied extractions overestimate the actual amount of reactive iron available for sulfide oxidation in the sediments of the Håkon Mosby Mud Volcano. As ascorbic acid and dithionite extract some iron-containing silicates (Kostka and Luther 1994) and the extruded material has iron-containing minerals like chlorite (Lein et al. 1998), in this setting the methods might extract a larger amount of other iron minerals than previously thought. Most iron-containing silicates have a low reactivity with sulfide, ranging from hundreds to thousands of years (Canfield et al. 1992).

Since the precipitation of pyrite produces sulfur isotope fractionations smaller than $1 \%$, the isotope composition of pyrite is a good approximation of the isotope composition of the source sulfide derived from SR. In sediments with SR rates of a similar magnitude to those reported here, pyrite that forms directly at the sediment surface is generally more depleted in ${ }^{34} \mathrm{~S}$ than is the pyrite in the Håkon Mosby Mud Volcano sediments (Lyons 1997; Schenau et al. 2002) as a result of biological isotope fractionation (Habicht and Canfield 1996). Strong ${ }^{34} \mathrm{~S}-$ enrichment of sedimentary sulfides is usually indicative of precipitation from ${ }^{34} \mathrm{~S}$-enriched dissolved sulfide (Brüchert et al. 2003; Dale et al. 2009). However, the homogeneity of the observed values with depth and between the three different sites supports a common allochthonous origin of the pyrite. We suggest that the pyrite in the mud volcano sediments derives largely from deeply buried sub-seafloor deposits and is transported upward with the mud-gas-fluid mixture. The slightly heavier $\delta^{34} \mathrm{~S}_{\mathrm{Avs}}$ in the sediments under the Beggiatoa mat indicates the reservoir effect of an evolving dissolved sulfide pool due to ongoing bacterial $\mathrm{SR}$. The much stronger ${ }^{34} \mathrm{~S}$-enrichment of near-surface AVS (e.g., compared to the sediments from the warm center [Fig. 4d,h]) indicates a smaller isotope effect from combined SR and sulfide oxidation, a result that is in agreement with recent modeling studies on sediment inhabited by the phylogenetically related large sulfur bacteria Thiomargarita (Brüchert et al. 2003; Dale et al. 2009). AVS is generally considered an intermediate in the formation of pyrite and during sulfide oxidation (Berner 1970; Schippers and Jørgensen 2002). The overall low concentrations of AVS throughout the cored sediment indicate that AVS, like pyrite, is not an important sulfide sink. Although we cannot provide quantitative estimates of the turnover time of the AVS fraction, it is likely that the

Table 4. Summary of oxygen fluxes ( $\mathrm{J}_{\mathrm{O}_{2}}$; with standard deviations), oxygen penetration depths, upward-directed sulfide fluxes $\left(\mathrm{J}_{\text {sulfide upward }}\right)$, and sulfate reduction rates (SRR) from different habitats of the Håkon Mosby Mud Volcano. Calculations and measurements are based on the in situ deployments of the microprofiler and on the ex situ sulfate reduction rates integrated over the upper $10 \mathrm{~cm}$. Displayed fluxes were calculated as diffusional fluxes and afterward were corrected for advection with a fluid upflow velocity as determined in de Beer et al. (2006). In the warm center an upflow rate of $1 \mathrm{~m} \mathrm{yr}^{-1}\left({ }^{*}\right)$ was assumed; only at an upflow rate of $\leq 1 \mathrm{~m} \mathrm{yr}^{-1}$ can sulfate penetrate to a depth of $2 \mathrm{~cm}$ and a sulfide peak form (Fig. 6b). An upflow velocity of $0.5 \mathrm{~m} \mathrm{yr}-1$ (**) was used for the Beggiatoa and next-to-Beggiatoa site; no correction was applied to the gray mat and next-to-gray mat site (upflow velocity: $0 \mathrm{~m}$ yr ${ }^{-1}$, see Discussion). The negative notation of the fluxes stands for fluxes from the water column into the sediment; the positive notation stands for fluxes from the sediment in the direction of the overlying water column. n.d., not determined. Standard deviations and averages are derived from replicate measurements $(n)$; for $\mathrm{J}_{\mathrm{O}_{2}}$ and $\mathrm{O}_{2}$ penetration depth $n=6$ for gray mat; $n=3$ for warm center, Beggiatoa, and next to gray mat; and $n=2$ for next to Beggiatoa. For SRR, $n=5$ for warm center, $n=8$ for Beggiatoa, and $n=2$ for gray mat.

\begin{tabular}{lcccl}
\hline \hline \multicolumn{1}{c}{ Habitat } & $\mathrm{J}_{\mathrm{O}_{2}}\left(\mathrm{mmol} \mathrm{m} \mathrm{d}^{-2}\right)$ & $\mathrm{O}_{2}$ penetration $(\mathrm{mm})$ & $\mathrm{J}_{\text {sulfide upward }}\left(\mathrm{mmol} \mathrm{m}^{-2} \mathrm{~d}^{-1}\right)$ & $\mathrm{SRR}\left(\mathrm{mmol} \mathrm{m}^{-2} \mathrm{~d}^{-1}\right)$ \\
\hline Warm center & $-11.4( \pm 3.7)^{*}$ & 1.3 & $0.7^{*}$ & $0.2-1.1 ;$ average: 0.5 \\
Beggiatoa & $-33.7( \pm 8.8)^{* *}$ & 0.5 & $11.6^{* *}$ & $2.8-23.1 ;$ average: 11.2 \\
Next to Beggiatoa & $-9.2( \pm 0.9)^{* *}$ & 3.0 & $7^{* *}$ & n.d. \\
Gray mat & $-45.2( \pm 8.4)$ & 0.5 & $17-131 ;$ average: 74 & $9.5-108 ;$ average: 59 \\
Next to gray mat & $-35.2( \pm 13)$ & 0.3 & 4.8 & n.d. \\
\hline
\end{tabular}


Table 5. Summary of nitrate uptake experiments with the calculated nitrate fluxes. Uptake was calculated from linear nitrate regression after a time period $>60 \mathrm{~min}$; values for nitrate loss due to diffusive uptake into the sediment were achieved with the COMSOL multiphysics model and have been subtracted.

\begin{tabular}{|c|c|c|c|}
\hline Habitat & $\begin{array}{c}\text { Nitrate concentration } \\
\text { before addition }\left(\mu \mathrm{mol} \mathrm{L} \mathrm{L}^{-1}\right)\end{array}$ & $\begin{array}{l}\text { Amount of nitrate } \\
\text { added }\left(\mu \mathrm{mol} \mathrm{L}^{-1}\right)\end{array}$ & $\begin{array}{c}\mathrm{J}_{\mathrm{NO}_{3}^{-}} \\
\left(\mathrm{mmol} \mathrm{m}^{-2} \mathrm{~d}^{-1}\right)\end{array}$ \\
\hline Warm center & 9 & $29(2 \times$ environmental concentration $)$ & -7 \\
\hline \multirow[t]{6}{*}{ Beggiatoa } & 4 & 14 (environmental concentration) & -10.8 \\
\hline & 1 & $29(2 \times$ environmental concentration $)$ & -26 \\
\hline & 6 & $52(4 \times$ environmental concentration $)$ & -102 \\
\hline & 6 & $270(18 \times$ environmental concentration $)$ & -40 \\
\hline & 184 & $310(30 \times$ environmental concentration $)$ & -74 \\
\hline & 3 & No nitrate addition & -1.5 \\
\hline Gray mat & 9 & $28(2 \times$ environmental concentration $)$ & -4.5 \\
\hline Control (seawater without sediment) & 13 & $29(2 \times$ environmental concentration $)$ & $-1.4 \times 10^{-4}$ \\
\hline
\end{tabular}
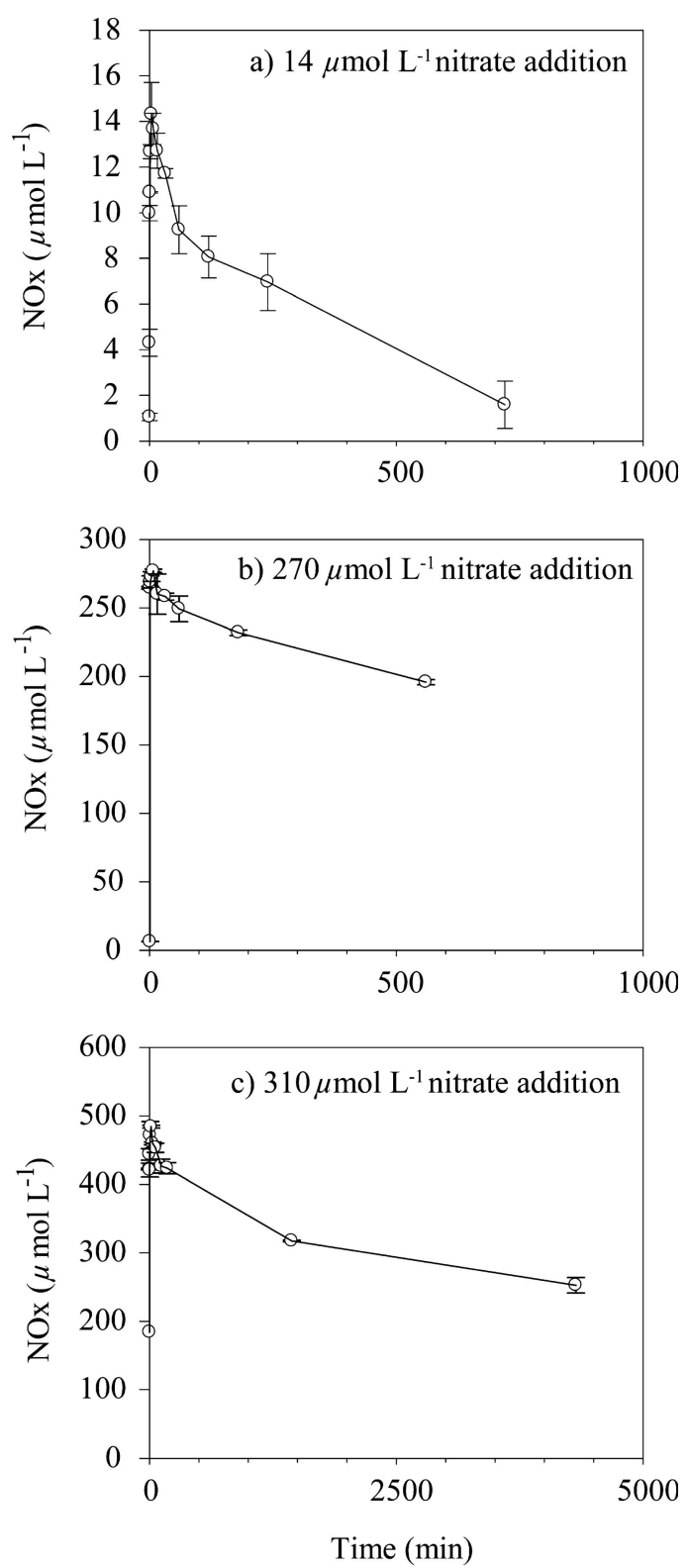

Fig. 9. Uptake of nitrate by Beggiatoa was measured in bottom water overlying a densely Beggiatoa-covered sediment. Different amounts of nitrate were added: (a) $14 \mu \mathrm{mol} \mathrm{L}-1$, (b) $270 \mu \mathrm{mol} \mathrm{L}-1$, and (c) $310 \mu \mathrm{mol} \mathrm{L}-1$ (see also Table 5). iron sulfides make up only a small fraction of the total sulfide turnover in these sediments, because the rate of supply of detrital reactive iron and the lack of bioturbating organisms limit the availability of reactive iron for ironsulfide formation.

Chemosynthetic biomass production: We observed that most of the sulfide oxidation at the Håkon Mosby Mud Volcano is carried out by sulfide-oxidizing bacteria. The sulfide flux could produce a biomass of 1.5-2.8 mol C $\mathrm{m}^{-2} \mathrm{yr}^{-1}$, according to the previously determined molar growth yield of sulfide oxidation (33-66\% of sulfide oxidation; Nelson et al. 1986; Hagen and Nelson 1997). Over the whole densely Beggiatoa-covered area, biomass production due to sulfide oxidation by Beggiatoa measures up to $8.4 \times 10^{4} \mathrm{~mol} \mathrm{C} \mathrm{yr}^{-1}$ (Table 6). Hence, a complete turnover of thiotrophic biomass occurs within $4 \mathrm{~d}$ (for the total habitat: $1.0 \times 10^{3} \mathrm{~mol} \mathrm{C}$ standing stock $/ 8.4 \times 10^{4} \mathrm{~mol}$ $\mathrm{C} \mathrm{yr}^{-1}$ yield). This is realistic, as the experimentally determined doubling time for Beggiatoa is approximately $1 \mathrm{~d}$ (Kamp et al. 2008), and high grazing pressure by dense nematode populations might control the standing stock (Van Gaever et al. 2006).

Compared to the molar growth yield of sulfide oxidation, that of AOM is very low $(2 \%$; Nauhaus et al. 2007) and yields only $0.11 \mathrm{~mol} \mathrm{C} \mathrm{m}^{-2} \mathrm{yr}^{-1}$, corresponding

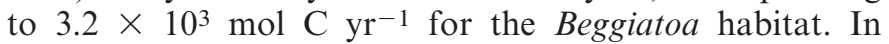
addition, in the surface sediment of this habitat aerobic methanotrophs are abundant (Lösekann et al. 2007). The biomass production from aerobic oxidation of methane is more difficult to calculate, as its molar growth yield has not been determined for cold-adapted deep-sea microorganisms. Culture experiments with mesophilic methanotrophs showed that the molar growth yield for aerobic oxidation of methane is around 67\% (Leak and Dalton 1986). Applying this ratio to the Beggiatoa habitat (for details see Table 6), this would amount to $0.8 \mathrm{~mol} \mathrm{C} \mathrm{m}^{-2} \mathrm{yr}^{-1}$, which would indicate that $2.5 \times 10^{4} \mathrm{~mol} \mathrm{C} \mathrm{yr}^{-1}$ could be fixed in the whole Beggiatoa habitat by aerobic oxidation of methane. This value might strongly overestimate the biomass gain in this habitat, as the growth yield for the aerobic methanotrophs might be much less at the in situ temperature of $0^{\circ} \mathrm{C}$. In summary, in this habitat the largest amount of biomass is most likely produced by Beggiatoa 
Table 6. Estimated annual primary production by thiotrophs and aerobic and anaerobic methanotrophs in the different habitats of the Håkon Mosby Mud Volcano. Consumption fluxes are based on the in situ measured sulfide fluxes (for anaerobic oxidation of methane $[\mathrm{AOM}]$ and sulfide oxidation) and the in situ measured oxygen flux in the warm center for aerobic methane oxidation (Table 4, converted to mol m $\left.\mathrm{m}^{-2} \mathrm{yr}^{-1}\right)$; assuming that * AOM equals sulfide consumption; $\uparrow$ aerobic methane oxidation in the Beggiatoa habitat and the hot center are the same as in the warm center; $\$$ sulfide oxidation proceeds geochemically in the warm center (see Discussion); and $\S$ all oxygen not used in geochemical sulfide oxidation is used in aerobic methane oxidation.

\begin{tabular}{|c|c|c|c|c|c|}
\hline & $\begin{array}{l}\text { Habitat } \\
\text { area }\left(\mathrm{m}^{2}\right)\end{array}$ & Consumption fluxes & $\begin{array}{l}\text { Biomass yield by } \\
\text { sulfide oxidation } \\
\quad\left(\mathrm{mol} \mathrm{C} \mathrm{yr}^{-1}\right)\end{array}$ & $\begin{array}{l}\text { Biomass yield } \\
\text { by AOM } \\
\left(\mathrm{mol} \mathrm{C} \mathrm{yr}^{-1}\right)\end{array}$ & $\begin{array}{l}\text { Biomass yield by aerobic } \\
\text { methane oxidation } \\
\left(\mathrm{mol} \mathrm{Cr}^{-1}\right)\end{array}$ \\
\hline \multirow[t]{2}{*}{ Beggiatoa habitat } & 30,000 & $\begin{array}{l}\text { Sulfide oxidation: } 4.23 \mathrm{~mol} \mathrm{~S} \\
\mathrm{~m}^{-2} \mathrm{yr}^{-1}\end{array}$ & $4.4 \times 10^{4}-8.4 \times 10^{4}$ & - & - \\
\hline & & $\begin{array}{l}\text { AOM: } 4.23 \text { mol S m-2 } \mathrm{yr}^{-1 *} \\
\text { Aerobic methane oxidation: } \\
\quad 3.7 \mathrm{~mol} \mathrm{O}_{2} \mathrm{~m}^{-2} \mathrm{yr}^{-1 \dagger}\end{array}$ & - & $3.2 \times 10^{3}$ & $2.5 \times 10^{4}$ \\
\hline Warm center & 101,000 & $\begin{array}{l}\text { AOM: } 0.26 \text { mol S m-2 } \mathrm{yr}^{-1} * \\
\text { Aerobic methane oxidation: } \\
\quad 3.7 \mathrm{~mol} \mathrm{O}_{2} \mathrm{~m}^{-2} \mathrm{yr}^{-1 \S}\end{array}$ & - & $6.5 \times 10^{2}$ & $8.3 \times 10^{4}$ \\
\hline Hot center & 14,000 & $\begin{array}{l}\text { Aerobic methane oxidation: } \\
\quad 3.7 \mathrm{~mol} \mathrm{O}_{2} \mathrm{~m}^{-2} \mathrm{yr}^{-1 \dagger}\end{array}$ & - & - & $1.2 \times 10^{4}$ \\
\hline
\end{tabular}

via the oxidation of sulfide, and AOM contributes only a minor fraction (Table 6).

Gray mat habitat - Sulfide production: Large differences in sulfide fluxes and SR rates and variable but relatively high temperature gradients (Tables 3, 4) indicate large heterogeneity of the gray mat habitat, which is most likely associated with dissociating gas hydrates. Sulfide concentrations were high and sulfide penetrated deep. However, the co-occurring deep sulfate penetration (Fig. 5p) is in conflict with the high sulfide concentration and flux. Such high sulfide concentrations, as measured here, only can be reached when sulfate is rapidly depleted and when diffusion is the dominant mass-transfer process. Diffusion as dominant mass-transport process in an otherwise advective geosystem can occur, for example, by spatial restricted blockage of fluid upflow by gas hydrates. In a diffusional system in steady state and with a complete conversion of sulfate to sulfide as the only S-converting process (e.g., no sulfide is oxidized), at any depth below the oxic zone,

$\mathrm{C}_{\mathrm{x}}$ sulfide $=\mathrm{C}_{0}$ sulfide $-\left(\mathrm{C}_{\mathrm{x}}\right.$ sulf ate $-\mathrm{C}_{0}$ sulf ate $) \times \frac{\mathrm{D}_{\text {sulfate }}}{\mathrm{D}_{\text {sulfide }}}(9)$

where $\mathrm{C}_{0}$ sulfide and $\mathrm{C}_{0}$ sulfate are sulfide and sulfate concentrations at the sediment-water interface, $\mathrm{C}_{\mathrm{x}}$ sulfide and $\mathrm{C}_{\mathrm{x}}$ sulfate are sulfide and sulfate concentrations at sediment depth $\mathrm{x}$, and $\mathrm{D}_{\text {sulfide }}$ and $\mathrm{D}_{\text {sulfate }}$ are molecular diffusion coefficients of the solutes in seawater $\left(D_{\text {sulfate }}=\right.$ $4.3 \times 10^{-5} \mathrm{~m}^{2} \mathrm{~d}^{-1} ;$ Li and Gregory 1974). With a seawater sulfate concentration of $28 \mathrm{mmol} \mathrm{L}^{-1}$ and when sulfide in the water column and sulfate at large depth are zero, the maximal concentration of sulfide is $17 \mathrm{mmol} \mathrm{L}^{-1}$. As our measurements show a concentration of $14 \mathrm{mmol} \mathrm{L}^{-1}$ (Fig. 8a), little or no advective pore-water flow occurs at the gray mat site. Furthermore, from the shape of the sulfide profile and the above equation it can be concluded that sulfate does not penetrate more than $2 \mathrm{~cm}$. In diffusive systems maximum sulfate penetration depth $\left(Z_{\text {sulfate }}\right)$ is controlled by SR and can be approximated according to the method of Jørgensen et al. (2004):

$$
Z_{\text {sulfate }}=\frac{D_{\text {Sed }} \text { sulfate } \phi C_{0} \text { sulfate }}{J_{\text {sulfate }}}
$$

with variables as defined previously and where $\mathbf{J}_{\text {sulfate }}$ is equal to the areal SR rate. Maximum sulfate penetration depth at the averaged depth-integrated SR rate $(59 \mathrm{mmol}$ $\mathrm{m}^{-2} \mathrm{~d}^{-1}$ ) is approximately $1 \mathrm{~cm}$, which is close to the penetration depth estimated before from the sulfide profile. The discrepancy in the measured pore-water concentrations can be explained by mixing of water-column sulfate with the gassy sediments during core recovery, which caused the sediments to bubble forcefully as a result of the pressure loss.

Biological sulfide oxidation: Whereas the sulfide flux measurements were variable, oxygen uptake rates were constant. As oxygen and sulfide profiles overlapped, part of the sulfide is oxidized aerobically and is fueling the mixed thiotrophic mat. Oxidation of sulfide to sulfate with oxygen as terminal electron acceptor occurs in a ratio of 2 to 1 :

$$
\mathrm{HS}^{-}+2 \mathrm{O}_{2} \rightarrow \mathrm{SO}_{4}^{2-}+\mathrm{H}^{+}
$$

Since the measured flux ratio was less than $1: 1$, the oxygen flux is too small to oxidize sulfide completely to sulfate. Elevated elemental sulfur concentrations in the upper part of the sediment indicate that sulfide is instead oxidized to elemental sulfur (Eq. 12), which can in turn be used either as electron acceptor by sulfate-reducing bacteria or can be further oxidized to sulfate by sulfide-oxidizing bacteria.

$$
2 \mathrm{HS}^{-}+\mathrm{O}_{2}+2 \mathrm{H}^{+} \rightarrow 2 \mathrm{~S}^{0}+2 \mathrm{H}_{2} \mathrm{O}
$$

Active nitrate uptake by the gray mat was indicated by the nitrate uptake experiments (Table 5). Since no sulfide 


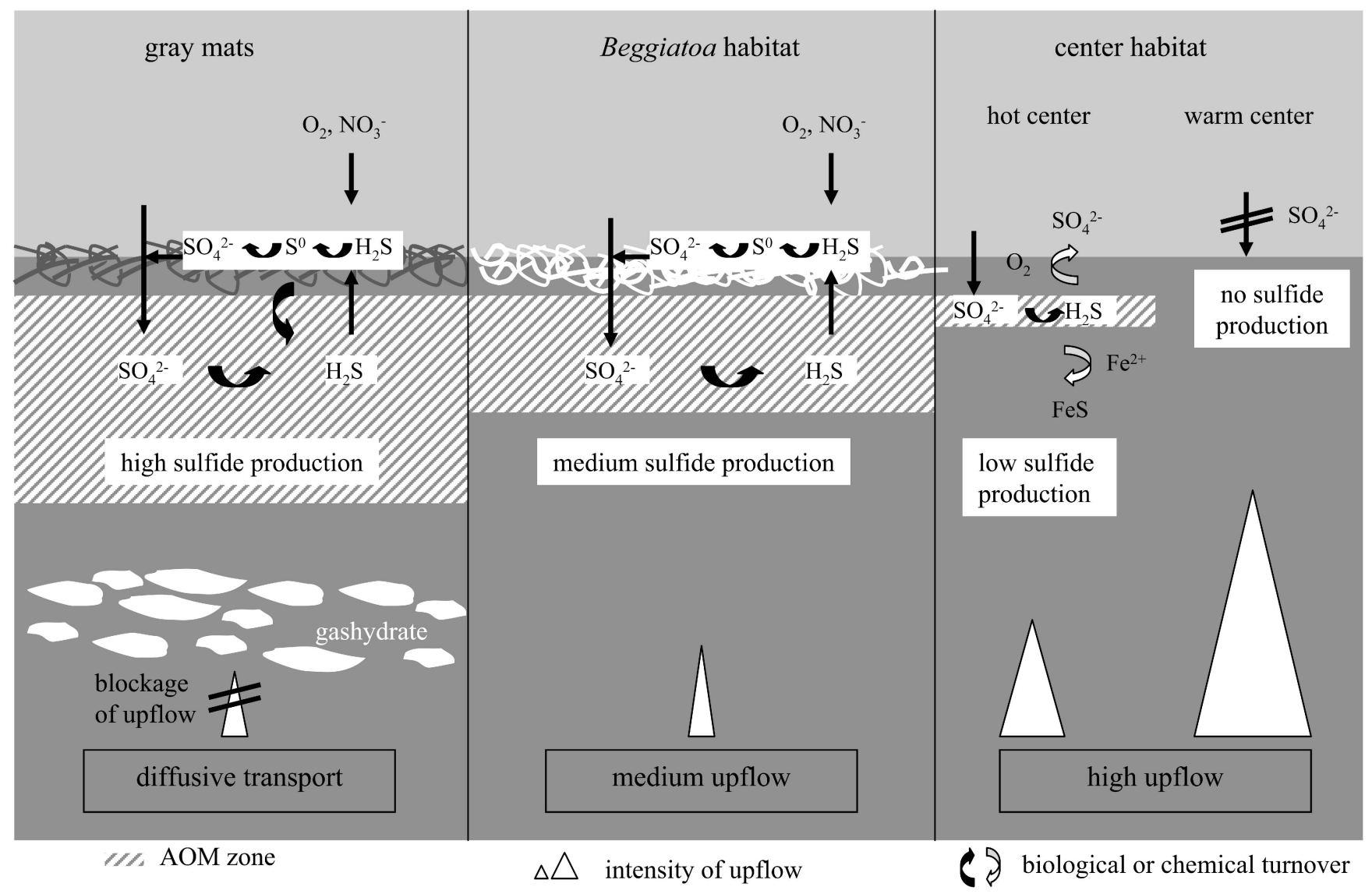

Fig. 10. Schema of the most important geochemical and microbiological processes in the three main habitats of the Håkon Mosby Mud Volcano.

leaked from the sediment, the sum of oxygen and nitrate fluxes should approximate the opposing sulfide flux if precipitation or chemical oxidation with iron is insignificant. Assuming an oxidation of sulfide to elemental sulfur, the nitrate flux into the gray mat habitat, therefore, will be maximally $1 / 4$ of the sulfide flux (Eq. 2). The morphological diversity and patchy white (sulfur-storing filaments) and gray (non-sulfur-storing filaments) mats hint at a patchwork of sulfide-oxidizing processes in this habitat. The density of motile bacteria that convert nitrate in the anoxic zone is too low to produce a gap between the oxic and the sulfidic zone.

Potential role of iron in sulfide oxidation: Sulfide oxidation takes place in the upper centimeter of the sediment (Fig. 8a). Only a very active iron oxidation cycle could supply the system with sufficient iron oxides to consume the high sulfide fluxes. No elevated concentrations of dithionite or ascorbic acid-extractable iron were found in the top centimeter of the sediment. Oxygen penetration depth $(0.5 \mathrm{~mm})$ was smaller than the mat thickness $(1 \mathrm{~mm})$, and, thus, all oxygen was consumed within the mat, leaving no oxygen for the chemical oxidation of sedimentary iron sulfides.

If the dithionite and ascorbic acid-extractable iron pool (Fig. $4 \mathrm{~m}$ ) had reacted with sulfide, elemental sulfur would have formed over the full depth and not only in the upper centimeter, where the thiotrophic community is present. $\mathrm{S}^{0}$ concentrations in the deeper sediment layers were in the same range as in the center site. Although pyrite concentrations were slightly elevated in the gray mat habitat, the isotopic composition does not show an AOM-derived signal for pyrite sulfur. As in the Beggiatoa habitat, the $\delta^{34} \mathrm{~S}$ values imply that pyrite originated from a deep source and was not recently formed.

The same arguments applicable to the Beggiatoa habitat hold for the role of iron oxides in sulfide oxidation in the gray mats: geochemical oxidation of sulfide does not limit bacterial primary production. The most important characteristic of this habitat seems to be its heterogeneity concerning SR and, thus, sulfide flux and diffusion as dominant mass transport processes. However, the gray mat habitat covers only a very small fraction of the Håkon Mosby Mud Volcano and may represent pioneer communities in transient AOM hotspots above dissociating gas hydrates.

Warm center site - Sulfide production: The decreased temperature gradient indicates substantially less fluid upflow in the outer rim northeast and south of the hot center, here referred to as warm center and marked by small elevations in the seafloor bathymetry (Fig. 1; 
Table 3). Low SR rates were measured at the northern site, and sulfide was detected in pore water and in situ microsensor measurements in the southern site. Obviously, decreased fluid upflow in contrast to the hot center allows some sulfate to penetrate the sediment and enables AOMdriven SR to some extent (de Beer et al. 2006).

Geochemical and biological turnover and chemosynthetic biomass production: In the warm center site $\mathrm{Fe}^{2+}$ is migrating upward with the mud volcano fluids with a flux of $0.1 \mathrm{mmol} \mathrm{m}^{-2} \mathrm{~d}^{-1}$ and is vanishing at the interface concurrent with sulfide. As the sulfide flux in this area is substantially lower than in all other habitats (Table 4), chemical immobilization with dissolved iron is significant and removes around $10 \%$ of the sulfide (Fig. 10). Precipitation of dissolved iron with isotopically light sulfide derived from AOM is visible in the sulfur isotope distribution (Fig. 4d). The isotope composition of AVS indicates the active involvement of this iron sulfide pool in the sulfur cycling near the sediment surface. The strong ${ }^{34} \mathrm{~S}$ depletion of AVS in the sediments from the warm center reflects the strong fractionation effect of sulfate-reducing bacteria under conditions at which sulfate is not limiting (Canfield 2001). Iron sulfides extracted in the AVS fraction are known to exchange sulfide rapidly with ambient pore water (Fossing and Jørgensen 1989). The continuous enrichment in AVS with depth in these sediments therefore indicates the exchange of iron-bound sulfide with coexisting hydrogen sulfide that becomes more ${ }^{34} \mathrm{~S}$-enriched with depth. Below $5 \mathrm{~cm}$ depth $\mathrm{FeS}$ showed an isotopic composition, as in other habitats, and this displays background values from the deep sediment source. No thiotrophic mat was visible on top of the center sediments. Sulfide and oxygen profiles did overlap (Fig. 6b), and 20\% of the oxygen flux will be used for oxidation of the remaining sulfide flux. This process might be purely chemical, as Lösekann et al. (2007) reported that the oxic surface of the center sediment is clearly dominated by methylotrophic Gammaproteobacteria (affiliated with Methylobacter and Methylophaga). At the warm mud volcano center the measured oxygen consumption by aerobic methanotrophs is equivalent to a maximal biomass production of $0.8 \mathrm{~mol} \mathrm{C} \mathrm{m} \mathrm{Cr}^{-2} \mathrm{yr}^{-1}$, corresponding to $8.3 \times$ $10^{4} \mathrm{~mol} \mathrm{C} \mathrm{yr}^{-1}$ (Table 6). However, as in the Beggiatoa habitat, this will be an overestimation, as the growth yield for aerobic methanotrophs at the prevailing temperature most probably is much less. Biomass production due to

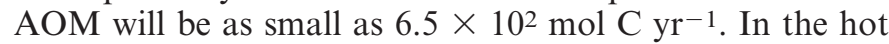
center only aerobic methane oxidation occurs. This produces a biomass of $0.8 \mathrm{~mol} \mathrm{C} \mathrm{m}-2 \mathrm{yr}^{-1}$ or $1.2 \times$ $10^{4} \mathrm{~mol} \mathrm{C} \mathrm{yr}^{-1}$ (Table 6). In total, approximately $9.5 \times$ $10^{4} \mathrm{~mol} \mathrm{C} \mathrm{yr}^{-1}$ might be formed related to methane oxidation in the center habitat of the Håkon Mosby Mud Volcano, mainly by aerobic oxidation. These are rough estimates, as the in situ energy yield for aerobic methane oxidation was so far not determined properly.

In conclusion, in high-fluid flow areas, such as the center of the Håkon Mosby Mud Volcano, only little sulfide is produced, geochemical sulfide oxidation processes predominate, and biomass production is largely limited to direct energy conservation from aerobic and anaerobic methane oxidation. However, in Håkon Mosby Mud Volcano habitats associated with methane-fueled sulfide production $>10 \mathrm{mmol} \mathrm{m}^{-2} \mathrm{~d}^{-1}$ thiotrophic mats formed. At reduced advective upflow extensive Beggiatoa mats were present; in areas with gray mats mass transport was mainly by diffusion, resulting in high sulfide concentrations close to the sediment surface. In both thiotrophic habitats geochemical sulfide oxidation was of minor importance. Fluxes of oxygen and nitrate were sufficient for a complete consumption of sulfide by the thiotrophs. Although methane oxidation coupled to SR is mandatory for the sulfide supply, primary productivity in the Beggiatoa and gray mat habitat of the Håkon Mosby Mud Volcano is in general dominated by thiotrophic bacteria.

\section{Acknowledgments}

We thank the shipboard crews and scientific parties of the ARK XIX/3b cruise with the R/V Polarstern, of the ATL05/02-3 cruise with the R/V L'Atalante, of the Viking cruise with the R/V Pourquoi pas?, and the ROV Victor 6000 team for help with the work at sea; Nina Weller, Hans Røy, and Susanne Hinck (MaxPlanck Institute for Marine Microbiology) for help with the bacterial samples; Michael Schlüter and Ludmilla Baumann (Alfred Wegener Institute for Polar and Marine Research) for providing the porosity data; Stefanie Grünke for preparing the sampling map; and Gaby Eickert, Ines Schröder, Vera Hübner, Karin Hohmann, Ingrid Dohrmann, Cecilia Wiegand, Martina Alisch, Andrea Schipper, and Martina Meyer for technical support. Thanks are due to Frank Wenzhöfer and the Sea-Tech technicians of the Microbial Habitat group (Max-Planck Institute for Marine Microbiology) for the construction and maintenance of the in situ devices. This study was supported by the GEOTECHNOLOGIEN project MUMM II (03G0608C) funded by the German Ministry of Education and Research (BMBF) and German Research Foundation (DFG); by the European Commission's Framework Six program Hotspot Ecosystem Research on the Margins of European Seas HERMES (GOCE-CT-2005511234-1); as well as by the Max-Planck and Helmholtz Societies. This is GEOTECH publication 1310.

\section{References}

Aloisi, G., M. Drews, K. Wallmann, and G. Bohrmann. 2004 Fluid expulsion from the Dvurechenskii mud volcano (Black Sea) - part I. Fluid sources and relevance to $\mathrm{Li}, \mathrm{B}, \mathrm{Sr}$, I and dissolved inorganic nitrogen cycles. Earth Planet. Sci. Lett. 225: 347-363.

Berner, R. A. 1970. Sedimentary pyrite formation. Am. J. Sci. 268: $1-23$.

Boetius, A., And E. Suess. 2004. Hydrate Ridge: A natural laboratory for the study of microbial life fueled by methane from near-surface gas hydrates. Chem. Geol. 205: 291-310, doi:10.1016/j.chemgeo.2003.12.034

- AND OTHERS. 2000. A marine microbial consortium apparently mediating anaerobic oxidation of methane. Nature 407: 623-626, doi:10.1038/35036572

Braman, R. S., And S. A. Hendrix. 1989. Nanogram nitrite and nitrate determination in environmental and biological materials by vanadium(III) reduction with chemiluminescence detection. Anal. Chem. 61: 2715-2718, doi:10.1021/ ac00199a007 
Brüchert, V., B. B. Jørgensen, K. Neumann, D. Riechmann, M. Schlösser, AND H. Schulz. 2003. Regulation of bacterial sulfate reduction and hydrogen sulfide fluxes in the central Namibian coastal upwelling zone. Geochim. Cosmochim. Acta 67: 4505-4518, doi:10.1016/S0016-7037(03)00275-8

CANFIELD, D. E. 1989. Reactive iron in marine sediments. Geochim. Cosmochim. Acta 53: 619-632, doi:10.1016/00167037(89)90005-7

2001. Isotope fractionation by natural populations of sulfate-reducing bacteria. Geochim. Cosmochim. Acta 65: 1117-1124, doi:10.1016/S0016-7037(00)00584-6

, R. Raiswell, and S. Bottrell. 1992. The reactivity of sedimentary iron minerals toward sulfide. Am. J. Sci. 292: 659-683.

Cline, J. D. 1969. Spectrophotometric determination of hydrogen sulfide in natural waters. Limnol. Oceanogr. 14: $454-458$.

Cordes, E. E., M. A. Arthur, K. Shea, R. S. Arvidson, and C. R. Fisher. 2005. Modeling the mutualistic interactions between tubeworms and microbial consortia. PLoS Biol. 3: 497-506, doi:10.1371/journal.pbio.0030077

Dale, A. W., V. Brüchert, M. Alperin, and P. Regnier. 2009. An integrated sulfur isotope model for Namibian shelf sediments. Geochim. Cosmochim. Acta 73: 1924-1944, doi:10.1016/j.gca.2008.12.015

de Beer, D., A. Glud, E. Epping, and M. Kühl. 1997. A fast responding $\mathrm{CO}_{2}$ microelectrode for profiling sediments, microbial mats and biofilms. Limnol. Oceanogr. 42: $1590-1600$.

DE BEERM, D., AND others. 2006. In situ fluxes and zonation of microbial activity in surface sediments of the Håkon Mosby Mud Volcano. Limnol. Oceanogr. 51: 1315-1331.

Drobner, E., H. Huber, G. Wächtershäuser, D. Rose, and K. O. Stetter. 1990. Pyrite formation linked with hydrogen evolution under anaerobic conditions. Nature 346: 742-744, doi: $10.1038 / 346742 \mathrm{a} 0$

Duperron, S., T. Nadalig, J. C. Caprais, M. Sibuet, A. FialaMedioni, R. Amann, And N. Dubilier. 2005. Dual symbiosis in a Bathymodiolus sp. mussel from a methane seep on the Gabon continental margin (southeast Atlantic): 16S rRNA phylogeny and distribution of the symbionts in gills. Appl. Environ. Microbiol. 71: 1694-1700, doi:10.1128/ AEM.71.4.1694-1700.2005

Ferdelman, T. G., T. M. Church, and G. W. Luther. 1991. Sulfur enrichment of humic substances in a Delaware salt marsh sediment core. Geochim. Cosmochim. Acta 55: 979-988, doi:10.1016/0016-7037(91)90156-Y

- C. Lee, S. Pantoja, J. Harder, B. M. Bebout, and H. Fossing. 1997. Sulfate reduction and methanogenesis in a Thioploca-dominated sediment off the coast of Chile. Geochim. Cosmochim. Acta 61: 3065-3079, doi:10.1016/S00167037(97)00158-0

Feseker, T., J.-P. Foucher, and F. Harmegnies. 2008. Fluid flow or mud eruptions? Sediment temperature distributions on Håkon Mosby Mud Volcano, SW Barents Sea slope. Mar. Geol. 247: 194-207, doi:10.1016/j.margeo.2007.09.005

Fossing, H., AND B. B. JøRGENSEN. 1989. Measurement of bacterial sulfate reduction in sediments: Evaluation of a single-step chromium reduction method. Biogeochemistry 8: 205-222, doi:10.1007/BF00002889

Foucher, J. P., AND others. 2009. Structure and drivers of cold seep ecosystems. Oceanography 22: 92-109.

Habicht, K., AND D. E. CANField. 1996. Sulphur isotope fractionation in modern microbial mats and the evolution of the sulphur cycle. Nature 382: 342-343, doi:10.1038/382342a0
Hagen, K. D., and D. C. Nelson. 1997. Use of reduced sulfur compounds by Beggiatoa spp.: Enzymology and physiology of marine and freshwater strains in homogeneous and gradient cultures. Appl. Environ. Microbiol. 63: 3957-3964.

Hall, P. O., and R. C. Aller. 1992. Rapid, small-volume, flow injection analysis for $\Sigma \mathrm{CO}_{2}$ and $\mathrm{NH}_{4}^{+}$in marine and freshwaters. Limnol. Oceanogr. 37: 1113-1119.

Hinck, S., T. R. Neu, G. Lavik, M. Mussmann, D. De Beer, and H. M. Jonkers. 2007. Physiological adaptation of a nitratestoring Beggiatoa sp. to diel cycling in a phototrophic hypersaline mat. Appl. Environ. Microbiol. 73: 7013-7022, doi:10.1128/AEM.00548-07

Huelstuen, B. O., O. Eldholm, J. I. Faleide, and P. R. Vogt. 1999. Regional setting of Håkon Mosby Mud Volcano, SW Barents Sea margin. Geo-Mar. Lett. 19: 22-28.

IVERSEN, N., AND B. B. JørGENSEN. 1993. Diffusion coefficients of sulfate and methane in marine sediments: Influence of porosity. Geochim. Cosmochim. Acta 57: 571-578, doi:10.1016/0016-7037(93)90368-7

Jerosch, K., M. Schlüter, J.-P. Foucher, A.-G. Allais, M. KlaGeS, AND C. EDy. 2007. Spatial distribution of mud flows, chemoautotrophic communities, and biogeochemical habitats at Håkon Mosby Mud Volcano. Mar. Geol. 243: 1-17, doi:10.1016/j.margeo.2007.03.010

Jeroschewski, P., C. Steuckart, and M. Kühl. 1996. An amperometric microsensor for the determination of $\mathrm{H}_{2} \mathrm{~S}$ in aquatic environments. Anal. Chem. 68: 4351-4357, doi:10.1021/ac960091b

JørGensen, B. B. 1978. A comparison of methods for the quantification of bacterial sulfate reduction in coastal marine sediments: 1. Measurements with radiotracer techniques. Geomicrobiol. J. 1: 11-27, doi:10.1080/01490457809377721

, M. E. Böttcher, H. Lüschen, L. N. Neretin, and I. I. Volkov. 2004. Anaerobic methane oxidation and a deep $\mathrm{H}_{2} \mathrm{~S}$ sink generate isotopically heavy sulfides in Black Sea sediments. Geochim. Cosmochim. Acta 68: 2095-2118, doi:10.1016/j.gca.2003.07.017

, AND N. P. Revsbech. 1985. Diffusive boundary layers and the oxygen uptake of sediments and detritus. Limnol. Oceanogr. 30: 111-122.

Kallmeyer, J., T. G. Ferdelman, A. Weber, H. Fossing, and B. B. JøRGENSEN. 2004. A cold chromium distillation procedure for radiolabeled sulfide applied to sulfate reduction measurements. Limnol. Oceanogr. Methods 2: 171-180.

Kamp, A., H. Røy, and H. N. Schulz-Vogt. 2008. Videosupported analysis of Beggiatoa filament growth, breakage, and movement. Microb. Ecol. 56: 484-491, doi:10.1007/ s00248-008-9367-x

- P. Stief, and H. N. Schulz-Vogt. 2006. Anaerobic sulfide oxidation with nitrate by a freshwater Beggiatoa enrichment culture. Appl. Environ. Microbiol. 72: 4755-4760, doi:10.1128/AEM.00163-06

KostKa, J. E., and G. W. Luther. 1994. Partitioning and speciation of solid phase iron in saltmarsh sediments. Geochim. Cosmochim. Acta 58: 1701-1710, doi:10.1016/ 0016-7037(94)90531-2

Leak, D. J., AND H. Dalton. 1986. Growth yields of methanotrophs: 1. Effect of copper on the energetics of methane oxidation. Appl. Microbiol. Biotechnol. 23: 470-476, doi:10.1007/BF02346062

Lein, A. Y., AND others. 1998. Geochemical features of gasbearing $\left(\mathrm{CH}_{4}\right)$ deposits of a submarine mud volcano in the Norwegian sea. Geokhimiya 3: 230-249.

Li, Y.-H., AND S. GRegory. 1974. Diffusion of ions in sea water and in deep-sea sediments. Geochim. Cosmochim. Acta 38: 703-714, doi:10.1016/0016-7037(74)90145-8 
Lösekann, T., K. Knittel, T. Nadalig, B. Fuchs, H. Niemann, A. Boetius, and R. Amann. 2007. Diversity and abundance of aerobic and anaerobic methane oxidizers at the Haakon Mosby Mud Volcano, Barents Sea. Appl. Environ. Microbiol. 73: 3348-3362, doi:10.1128/AEM.00016-07

, A. Robador, H. Niemann, K. Knittel, A. Boetius, and N. DubiLier. 2008. Endosymbioses between bacteria and deep-sea siboglinid tubeworms from an Arctic cold seep (Haakon Mosby Mud Volcano, Barents Sea). Environ. Microbiol. 10: 3237-3254, doi:10.1111/j.1462-2920.2008. 01712.x

Luther, G. W. 1991. Pyrite synthesis via polysulfide compounds. Geochim. Cosmochim. Acta 55: 2839-2849, doi:10.1016/00167037(91)90449-F

Lyons, T. W. 1997. Sulfur isotopic trends and pathways of iron sulfide formation in upper Holocene sediments of the anoxic Black Sea. Geochim. Cosmochim. Acta 61: 3367-3382, doi:10.1016/S0016-7037(97)00174-9

Mchatton, S. C., J. P. Barry, H. W. Jannasch, and D. C. Nelson. 1996. High nitrate concentrations in vacuolate, autotrophic marine Beggiatoa spp. Appl. Environ. Microbiol. 62: 954-958.

Milkov, A. V., P. R. Vogt, K. Crane, A. Y. Lein, R. Sassen, and G. A. Cherkashev. 2004. Geological, geochemical, and microbial processes at the hydrate-bearing Håkon Mosby Mud Volcano: A review. Chem. Geol. 205: 347-366, doi:10.1016/j.chemgeo.2003.12.030

Mussmann, M., AND others. 2003. Phylogeny and distribution of nitrate-storing Beggiatoa spp. in coastal marine sediments. Environ. Microbiol. 5: 523-533, doi:10.1046/j.14622920.2003.00440.x

Nauhaus, K., M. Albrecht, M. Elvert, A. Boetius, and F. WiDDEL. 2007. In vitro cell growth of marine archaealbacterial consortia during anaerobic oxidation of methane with sulfate. Environ. Microbiol. 9: 187-196, doi:10.1111/ j.1462-2920.2006.01127.x

Nelson, D. C., B. B. Jørgensen, and N. P. Revsbech. 1986. Growth pattern and yield of a chemoautotrophic Beggiatoa sp. in oxygen-sulfide microgradients. Appl. Environ. Microbiol. 52: 225-233.

Niemann, H., And others. 2006. Novel microbial communities of the Haakon Mosby Mud Volcano and their role as a methane sink. Nature 443: 854-858, doi:10.1038/nature 05227

Preisler, A., D. de Beer, A. Lichtschlag, G. Lavik, A. Boetius, AND B. B. JørGeNSEN. 2007. Biological and chemical sulfide oxidation in a Beggiatoa inhabited marine sediment. ISME J. 1: $341-353$.

Revsbech, N. P., And D. M. Ward. 1983. Oxygen microelectrode that is insensitive to medium chemical composition - use in an acid microbial mat dominated by Cyanidium caldarium. Appl. Environ. Microbiol. 45: 755-759.

Sahling, H., D. Rickert, R. W. Lee, P. Linke, and E. Suess. 2002. Macrofaunal community structure and sulfide flux at gas hydrate deposits from the Cascadia convergent margin, NE Pacific. Mar. Ecol. Prog. Ser. 231: 121-138, doi:10.3354/ meps 231121
Sayama, M., N. Risgaard-Petersen, L. P. Nielsen, H. Fossing, And P. B. Christensen. 2005. Impact of bacterial $\mathrm{NO}_{3}{ }^{-}$ transport on sediment biogeochemistry. Appl. Environ. Microbiol. 71: 7575-7577, doi:10.1128/AEM.71.11.75757577.2005

Schenau, S. J., H. F. Passier, G. J. Reichart, and G. J. de Lange. 2002. Sedimentary pyrite formation in the Arabian Sea. Mar. Geol. 185: 393-402, doi:10.1016/S0025-3227(02)00183-4

Schippers, A., AND B. B. Jørgensen. 2002. Biogeochemistry of pyrite and iron sulfide oxidation in marine sediments. Geochim. Cosmochim. Acta 66: 85-92, doi:10.1016/S00167037(01)00745-1

Sibuet, M., And K. Olu. 1998. Biogeography, biodiversity and fluid dependence of deep-sea cold-seep communities at active and passive margins. Deep-Sea Res. II 45: 517-567, doi:10.1016/S0967-0645(97)00074-X

Stookey, L. L. 1970. Ferrozine-a new spectrophotometric reagent for iron. Anal. Chem. 42: 779-781, doi:10.1021/ ac60289a016

Teske, A., And D. C. Nelson. 2006. The genera Beggiatoa and Thioploca, p. 784-810. In M. Dworkin, S. Falkow, E. Rosenberg, K.-H. Schleifer, and E. Stackebrandt [eds.], Prokaryotes. Springer.

Treude, T., A. Boetius, K. Knittel, K. Wallmann, and B. B. JørGensen. 2003. Anaerobic oxidation of methane above gas hydrates at Hydrate Ridge, NE Pacific Ocean. Mar. Ecol. Prog. Ser. 264: 1-14, doi:10.3354/meps264001

Van Gaever, S., L. Moodley, D. De Beer, and A. Vanreusel. 2006. Meiobenthos at the Arctic Håkon Mosby Mud Volcano, with a parental-caring nematode thriving in sulphide-rich sediments. Mar. Ecol. Prog. Ser. 321: 143-155, doi:10.3354/meps321143

Vogt, P. R., AND others. 1997. Haakon Mosby Mud Volcano provides unusual example of venting. EOS 78: 549-557, doi:10.1029/97EO00326

Wallmann, K., M. Drews, G. Aloisi, and G. Bohrmann. 2006. Methane discharge into the Black Sea and the global ocean via fluid flow through submarine mud volcanoes. Earth Planet. Sci. Lett. 248: 545-560.

Wenzhöfer, F., O. Holby, R. N. Glud, H. K. Nielsen, And J. K. Gundersen. 2000. In situ microsensor studies of a shallow water hydrothermal vent at Milos, Greece. Mar. Chem. 69: 43-54, doi:10.1016/S0304-4203(99)00091-2

Zopfi, J., T. G. Ferdelman, And H. Fossing. 2004. Distribution and fate of sulfur intermediates - sulfite, tetrathionate, thiosulfate, and elemental sulfur-in marine sediments, p. 97-116. In J. P. Amend, K. Edwards, and T. W. Lyons [eds.], Sulfur biogeochemistry: Past and present. Geological Society of America Special Paper.

Associate editor: Bo Thamdrup

Received: 05 June 2009 Accepted: 26 October 2009 Amended: 17 December 2009 